University of Nebraska - Lincoln

DigitalCommons@University of Nebraska - Lincoln

\title{
Holocene landscape response to seasonality of storms in the Mojave Desert
}

\author{
David M. Miller \\ U.S. Geological Survey, 345 Middlefield Road, MS-973, Menlo Park, CA 94025, USA \\ Kevin M. Schmidt \\ U.S. Geological Survey, 345 Middlefield Road, MS-973, Menlo Park, CA 94025, USA \\ Shannon A. Mahan \\ U.S. Geological Survey, Box 25046, Denver Federal Center, Denver, CO 80225, USA \\ John P. McGeehin \\ U.S. Geological Survey, 12201 Sunrise Valley Drive, Reston, VA 20192, USA \\ Lewis A. Owen \\ Department of Geology, University of Cincinnati, Cincinnati, $\mathrm{OH} 45221$, USA \\ See next page for additional authors
}

Follow this and additional works at: https://digitalcommons.unl.edu/usgsstaffpub

Part of the Earth Sciences Commons

Miller, David M.; Schmidt, Kevin M.; Mahan, Shannon A.; McGeehin, John P.; Owen, Lewis A.; Barron, John A.; Lehmkuhl, Frank; and Lohrer, Rene, "Holocene landscape response to seasonality of storms in the Mojave Desert" (2010). USGS Staff -- Published Research. 259.

https://digitalcommons.unl.edu/usgsstaffpub/259

This Article is brought to you for free and open access by the US Geological Survey at DigitalCommons@University of Nebraska - Lincoln. It has been accepted for inclusion in USGS Staff -- Published Research by an authorized administrator of DigitalCommons@University of Nebraska - Lincoln. 


\section{Authors}

David M. Miller, Kevin M. Schmidt, Shannon A. Mahan, John P. McGeehin, Lewis A. Owen, John A. Barron, Frank Lehmkuhl, and Rene Lohrer 


\title{
Holocene landscape response to seasonality of storms in the Mojave Desert
}

\author{
David M. Miller ${ }^{\mathrm{a}, *}$, Kevin M. Schmidt ${ }^{\mathrm{a}}$, Shannon A. Mahan ${ }^{\mathrm{b}}$, John P. McGeehin ${ }^{\mathrm{c}}$, Lewis A. Owen ${ }^{\mathrm{d}}$, \\ John A. Barron ${ }^{\text {a }}$, Frank Lehmkuhl ${ }^{\mathrm{e}}$, Rene Löhrer ${ }^{\mathrm{e}}$ \\ ${ }^{a}$ U.S. Geological Survey, 345 Middlefield Road, MS-973, Menlo Park, CA 94025, USA \\ ${ }^{\mathrm{b}}$ U.S. Geological Survey, Box 25046, Denver Federal Center, Denver, CO 80225, USA \\ ${ }^{c}$ U.S. Geological Survey, 12201 Sunrise Valley Drive, Reston, VA 20192, USA \\ d Department of Geology, University of Cincinnati, Cincinnati, OH 45221, USA \\ ${ }^{\mathrm{e}}$ Department of Geography, RWTH Aachen University, Templergraben 55, GER-52056 Aachen, Germany
}

\section{A R T I C L E I N F O}

Article history:

Available online 13 October 2009

\begin{abstract}
A B S T R A C T
New optically stimulated and radiocarbon ages for alluvial fan and lake deposits in the Mojave Desert are presented, which greatly improves the temporal resolution of surface processes. The new Mojave Desert climate-landscape record is particularly detailed for the late Holocene. Evidence from ephemeral lake deposits and landforms indicates times of sustained stream flow during a wet interval of the latter part of the Medieval Warm Period at ca. AD 1290 and during the Little Ice Age at ca. AD 1650. The former lakes postdate megadroughts of the Medieval Warm Period, whereas the latter match the Maunder Minimum of the Little Ice Age. Periods of alluvial fan aggradation across the Mojave Desert are 14-9 cal ka and 63 cal ka. This timing largely correlates to times of increased sea-surface temperatures in the Gulf of California and enhanced warm-season monsoons. This correlation suggests that sustained alluvial fan aggradation may be driven by intense summer-season storms. These data suggest that the close proximity of the Mojave Desert to the Pacific Ocean and the Gulf of California promotes a partitioning of landscape-process responses to climate forcings that vary with seasonality of the dominant storms. Coolseason Pacific frontal storms cause river flow, ephemeral lakes, and fan incision, whereas periods of intense warm-season storms cause hillslope erosion and alluvial fan aggradation. The proposed landscape-process partitioning has important implications for hazard mitigation given that climate change may increase sea-surface temperatures in the Gulf of California, which indirectly could increase future alluvial fan aggradation.
\end{abstract}

(c) 2009 Elsevier Ltd and INQUA. All rights reserved.

\section{Introduction}

Human-induced global climate change is currently projected to impact deserts more severely than many other terrestrial environments (Parry et al., 2008, 2007). In particular, climatic drivers in deserts are strongly linked with geologic hazards, such as landslides, debris flows, floods, fluvial and aeolian sediment erosion and deposition, and many other geologic surface processes (Cooke et al., 1982; Bull, 1991; Bullard et al., 2007). Future human-induced climate change will, therefore, profoundly affect and transform desert landscapes and ecosystems, which in turn will impact people and the ecological integrity of dryland environments. The deserts of the southwest United States, with their growing human populations and their importance for infrastructure and for military

\footnotetext{
* Corresponding author. Tel.: +1 6503294923.

E-mail address: dmiller@usgs.gov (D.M. Miller).
}

and park lands, face an uncertain future given the likely changes. This paper examines the environmental changes that have taken place during the Holocene to more fully explore the relationship between climate, surface processes and landscape evolution. This in turn allows better understanding and prediction of environmental change in the deserts of the southwest United States.

Despite the pressing need for assessing climate change impacts in deserts, making accurate assessments is difficult for several reasons, including: (1) climate models generally have low fidelity in deserts; (2) deserts have less well-developed paleoclimate and paleobotanical records due to poor preservation of material; and (3) dating desert deposits to evaluate temporal linkages between geologic processes and climate events is challenging, largely due to oxidation of organic materials. Deserts, however, tend to have excellent preservation of geomorphology and deposits, which can be interpreted in terms of surface processes and relative ages based on features such as pedogenesis and modification of original depositional architecture. As a result, increasing knowledge of 
linkages between past surface processes and climate variability in desert environments requires improved dating of deposits and events and improved knowledge of past climate change and variability.

Lacustrine and wetland sediments are the best-dated deposits in deserts (e.g., Quade et al., 2003; Wells et al., 2003) because these deposits contain aquatic shells and organic matter that can be preserved. Other deposits are strongly oxidized in arid climates and hence lack organic matter. As a result, and because paleo-hydrologic information is associated with the dated deposits, many climatic interpretations are tied to these wet locations, which typically constitute less than $5 \%$ of the landscape, and principally lie in the valley bottoms. Dunefields are moderately well-dated by luminescence methods and can be tied to distinct climatic episodes (e.g., Lancaster and Tchakerian, 2003). Most of the desert landscape, however, comprises steep, variably soil-mantled hillslopes, alluvial piedmonts, and valley-bottom playas and stream systems. These remain poorly dated and only a few studies have attempted to tie them to climate models. This is unfortunate since a considerable amount of information regarding desert landscape evolution has not been examined and therefore the likely changes in much of the desert landscape have not been assessed to assemble a holistic view of landscape response and potential linkages.

This paper focuses on developing a chronology for alluvial fan, alluvial piedmont, and valley-bottom deposits that areally constitute the majority of the Mojave Desert environment. These deposits are dated by applying optically stimulated luminescence (OSL) methods building on the work of Mahan et al. (2007a,b) as well as radiocarbon dating of lake and wetland deposits. The improved chronology supports early work that lakes are formed by coolseason climate events (Enzel and Wells, 1997) and shows that alluvial fan aggradation is not synchronous with lake deposition. Times of alluvial fan aggradation correlate with times of high seasurface temperatures in nearby subtropical seas, which supports the view that warm-season monsoon precipitation drives fan aggradation. A surfice-process-response model, driven by storm intensity and seasonality of precipitation, is proposed for how dryland landscapes respond to climate variability. If the model is supported by future work, seasonality of precipitation may be an important consideration for forecasting climate change impacts.

\section{Previous studies}

Early investigations of surface processes in the Mojave Desert include several studies of Pleistocene lake basins (e.g., Thompson, 1929; Blackwelder, 1954; Ore and Warren, 1971) and insightful studies of alluvial piedmonts (Hunt and Mabey, 1966; Carr and Dickey, 1980; Bull, 1991). These studies recognized that paleolake shorelines were occupied by humans during brief intervals of the Holocene and that alluvial fans bordering mountain ranges developed episodically. Soils-geomorphic approaches (Birkeland, 1999) advanced the concept that discrete alluvial fan depositional units possessing distinctive soils could be mapped, but reliable methods for dating alluvial fans were few, and the climate interpretations of the soils-geomorphic units have been elusive. For instance, it remained unknown whether the characteristic soils in these mapped fan units represented episodes with distinctive climate characteristics, which imparted distinct soils, and (or) discrete intervals of alluvial fan activity separated by depositional hiatuses of little activity. A key concept is that the age- and soils-specific groups of deposits are climate-driven, both as depositional pulses and as specific climate-influenced soils. As a result, deposits have been shown to be nearly synchronous across broad regions (Menges et al., 2001). In one of the first alluvial fan process models invoking climate change, Bull (1991) proposed that widespread fan aggradation at approximately the termination of the Last Glacial Maximum (LGM) was driven by warming and drying, reduced plant cover, and increased erodibility of the desert landscape. This model was supported by Reheis et al. (1996) in Fish Lake Valley in the southern Great Basin Desert (Fig. 1) where widespread distal fan deposits interbedded with marsh deposits were dated to this time interval by radiocarbon methods.

As regional and local understanding of the detailed nature and complexity of paleoclimate change at the Pleistocene-Holocene transition improved, it became apparent that climate was highly variable for several millennia after the LGM, and climate conditions in this area considered typical of the Holocene did not ensue until well after the onset of the Bølling-Alleröd. For instance, Wells et al. (2003) demonstrated that pluvial Lake Mojave in the central Mojave Desert was intermittently present until about 11 ka based on radiocarbon dating of lake sediment and shells. Similarly, D.E. Anderson and S.G. Wells (2003) demonstrated that pluvial conditions in Death Valley persisted until about $12.5 \mathrm{ka}$. Koehler et al. (2005) demonstrated that botanical remains in woodrat middens in the central Mojave Desert indicate plant communities did not shift from those typical of the full glacial until about $11 \mathrm{cal} \mathrm{ka}$, and transitioned through a mesophytic shrub stage from 11 to $\sim 8.7$ cal ka before shifting to xerophytic assemblages.

As improved paleoclimate data started to reveal the structure of the Pleistocene-Holocene transition more precisely, initial ages for the associated alluvial fan aggradation cycle suggested that it postdated the LGM termination significantly. McDonald et al. (2003) noted these difficulties with the Bull model for alluvial fan aggradation and hypothesized that enhanced tropical cyclone activity during the $\sim 12-10$ cal ka period of fan aggradation caused hillslope erosion and fan aggradation.

Dating of lake records associated with the Mojave River, which heads in the Transverse Ranges, demonstrated that extended river flow and multi-decade long terminal lakes were associated with the Little Ice Age (LIA) and a period at about $3.8 \mathrm{ka}$ (Enzel and Wells,

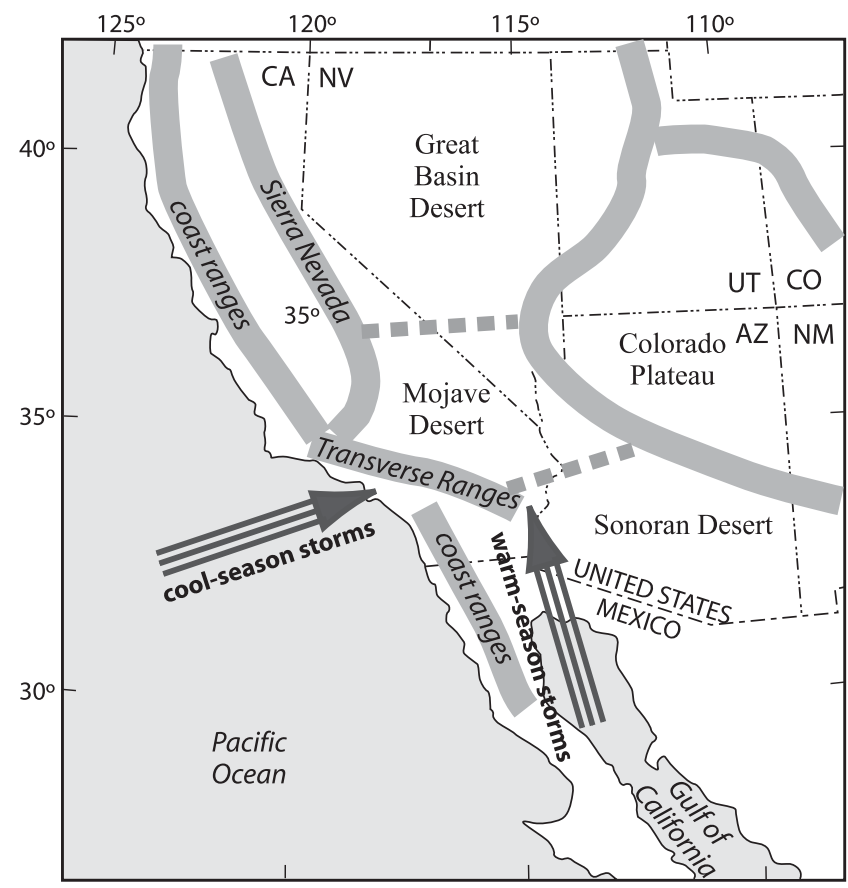

Fig. 1. Location map of the Mojave Desert and physiography of the region. Large arrows show predominate storm patterns for warm- and cool-season precipitation that is facilitated by proximity of the Mojave Desert to two contrasting water bodies. 
Table 1

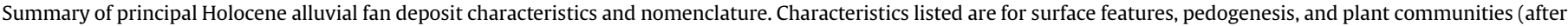
Menges and Miller, 2007; Miller et al., 2009). Av = vesicular A horizon, B=B horizon, $\mathrm{K}=$ calcic horizon.

\begin{tabular}{|c|c|c|c|c|c|c|c|}
\hline $\begin{array}{l}\text { Map } \\
\text { unit }\end{array}$ & Surface & Pavement & Varnish & $A v$ & B & $\mathrm{K}$ & Plants \\
\hline Qya1 & Active wash or fan & None & None & None & None & None & Few; cheesebush \\
\hline Qya2 & Bar and swale strong & None & None to v. weak & Generally none & None & None & Creosote bush, white bursage \\
\hline Qya3 & $\begin{array}{l}\text { Remnant bar and swale, } \\
\text { somewhat flat }\end{array}$ & Incipient & Weak & Weak - sandy silt & $\begin{array}{l}\text { Weak (Bw) } \\
\text { reddish }\end{array}$ & Stage I & Creosote bush, white bursage \\
\hline Qya4 & $\begin{array}{l}\text { Weak remnant bar and } \\
\text { swale, fairly flat }\end{array}$ & $\begin{array}{l}\text { Weak - some leveling } \\
\text { of pebbles }\end{array}$ & $\begin{array}{l}\text { Weak to } \\
\text { moderate }\end{array}$ & $\begin{array}{l}\text { Weak to moderate - } \\
\text { sandy silt }\end{array}$ & Bw & Stage I -II & Creosote bush, white bursage \\
\hline
\end{tabular}

1997). Both events have temporally consistent analogs in several lake basins and in downward elevational shifts of vegetation zones over the greater Mojave Desert region (Enzel and Wells, 1997). By comparing historical terminal lake development with rainfall and stream discharge records, these researchers argued that extreme winter storms occurring for a decade or more are needed to sustain the ephemeral lakes. Detailed mapping and an extensive program of numerical dating is therefore needed to examine the links between climatically driven surface processes and landscape evolution.

\section{Methods}

Surficial geology was mapped in detail $(1: 24,000)$ in key areas (e.g., Bedford, 2003; Dudash, 2006; Miller and Amoroso, 2006) as well as in intermediate scale $(1: 100,000)$ across much of the Mojave Desert (e.g., Amoroso and Miller, 2006; Bedford et al., 2006; Schmidt and McMackin, 2006). Standard field methods were used, including description of landforms, soils, and deposits; interpretation of aerial photographs; interpretation of topographic data sets (30-m DEMs and 1-m LiDAR); and remote sensing (Landsat 7 and Digital Orthophotograph Quarter Quadrangles). Alluvial fan units distinguished by soils-geomorphic approaches (Birkeland, 1999) are summarized in Table 1. Map units were defined on the basis of both age of the deposit and process of deposition, and locally by material type. Two widespread map units are referred to in this report: Qya4, which refers to alluvial fan deposits that bracket the Pleistocene-Holocene boundary, and Qya3, which refers to alluvial fan deposits of middle Holocene age (Table 1; Miller et al., 2009). Deposits that were associated with the geologic mapping were dated using OSL and radiocarbon $\left({ }^{14} \mathrm{C}\right)$ methods. The locations and stratigraphic contexts for samples are given in Table 2 .

\subsection{Radiocarbon dating}

Shell samples collected for radiocarbon dating were selected in the field on the basis of lack of weathering and for the presence of pearly luster (in the case of Anodonta shells). Radiocarbon samples for this study were processed at the U.S. Geological Survey's (USGS) graphite laboratory in Reston, Virginia, and dated by accelerator mass spectrometry (AMS) at the Center for Accelerator Mass Spectrometry (CAMS) in Lawrence Livermore National Laboratory in California. The radiocarbon data and results are presented in Table 3. Samples of charcoal and other organic materials were given a standard acid-alkali-acid pretreatment consisting of consecutive washes in $1 \mathrm{M} \mathrm{HCl}\left(2 \mathrm{~h}, 60^{\circ} \mathrm{C}\right), 0.1 \mathrm{M} \mathrm{NaOH}$ (overnight, $60^{\circ} \mathrm{C}$ ) and $1 \mathrm{M} \mathrm{HCl}\left(2 \mathrm{~h}, 60^{\circ} \mathrm{C}\right)$. Mollusk shells were picked under microscope, sonicated, and treated by acid leaching with dilute $\mathrm{HCl}$. All samples were converted to $\mathrm{CO}_{2}$ through combustion (organic carbon samples) or acid hydrolysis (shell samples) and converted to graphite over iron in the presence of $\mathrm{H}_{2}$ at $575{ }^{\circ} \mathrm{C}$.

Table 2

Locations and context for dated samples.

\begin{tabular}{|c|c|c|c|c|c|}
\hline Sample Number & Location & UTM E ${ }^{a}$ & $\mathrm{UTM} \mathrm{N}^{\mathrm{a}}$ & Dating Method & Stratigraphic context \\
\hline M03SM-1686 & Coyote Wash & 522,313 & $3,875,008$ & ${ }^{14} \mathrm{C}$ & Lake beds overlain by Qya4 \\
\hline M06LA-428 & Rosamond Lake & 405,378 & $3,857,486$ & ${ }^{14} \mathrm{C}$ & Playa-margin lake sediment \\
\hline M06SM-163A1 & East Cronese Lake & 567,187 & $3,887,202$ & ${ }^{14} \mathrm{C}$ & Upright shell in upper sand bed \\
\hline M06SM-163A2 & East Cronese Lake & 567,187 & $3,887,202$ & ${ }^{14} \mathrm{C}$ & Upright shell in upper sand bed \\
\hline M06SM-163B2 & East Cronese Lake & 567,187 & $3,887,202$ & ${ }^{14} \mathrm{C}$ & Charcoal in or on upper sand bec \\
\hline M05IV-2365 & Tough Nut Wash & 630,013 & $3,875,961$ & ${ }^{14} \mathrm{C}$ & Hearth overlying Qya4 \\
\hline PT1 Fossaria & Chambless GWD & 639,525 & $3,818,044$ & ${ }^{14} \mathrm{C}$ & Upper bed below Qya4 \\
\hline PT1 Pupillid & Chambless GWD & 639,525 & $3,818,044$ & ${ }^{14} \mathrm{C}$ & Upper bed below Qya4 \\
\hline Cronese1 & East Cronese Lake & 567,187 & $3,887,202$ & OSL & Lake sand, $23 \mathrm{~cm}$ depth \\
\hline Cronese2 & East Cronese Lake & 567,187 & $3,887,202$ & OSL & Lake sand, $65 \mathrm{~cm}$ depth \\
\hline Cronese3 & East Cronese Lake & 567,187 & $3,887,202$ & OSL & Lake sand, $210 \mathrm{~cm}$ depth \\
\hline M05CL-19 & Grassy Valley & 477,828 & $3,902,734$ & OSL & GWD beneath Qya4 \\
\hline M02VI-989 & Sheep Creek fan & 451,338 & $3,829,441$ & OSL & Base of exposure \\
\hline M02VI-990 & Sheep Creek fan & 451,327 & $3,829,443$ & OSL & Top of deposit \\
\hline B02AM-391A & Chambless GWD & 636,494 & $3,822,725$ & OSL & GWD beneath Qya4 \\
\hline B02AM-391B & Chambless GWD & 636,494 & $3,822,725$ & OSL & GWD beneath Qya4 \\
\hline B02AM-393 & Fenner Wash & 658,533 & $3,843,945$ & OSL & Qya4 deposit inset into older fan \\
\hline B02AM-394 & Fenner Wash & 658,478 & $3,843,965$ & OSL & Qia1? distal fan deposit \\
\hline M05AM-28 & Chambless GWD & 639,525 & $3,818,044$ & OSL & Top of GWD (shell bed) \\
\hline JY99-55 & Kelso Wash GWD & 594,631 & $3,876,604$ & OSL & Upper GWD sand \\
\hline JY99-56 & Kelso Wash GWD & 594,667 & $3,876,584$ & OSL & Lower GWD near base \\
\hline KS04-IV-33 & Tough Nut Fan & 630,013 & $3,875,961$ & OSL & Base of active wash deposit \\
\hline
\end{tabular}

${ }^{\text {a }}$ UTM coordinates in NAD 83 datum, zone 11. 
Table 3

Radiocarbon ages, Mojave Desert. Location numbers shown in Fig. 2.

\begin{tabular}{|c|c|c|c|c|c|c|c|c|c|}
\hline \multirow[t]{2}{*}{ Sample Number } & \multirow[t]{2}{*}{ Location Number } & \multirow[t]{2}{*}{ Lab Number } & \multirow[t]{2}{*}{ Material Dated } & \multirow[t]{2}{*}{$\delta{ }^{13} \mathrm{C}^{\mathrm{a}}$} & \multirow[t]{2}{*}{${ }^{14} \mathrm{C}$ age } & \multirow[t]{2}{*}{ Error } & \multicolumn{3}{|c|}{ Calibrated age ${ }^{\mathrm{b}}$} \\
\hline & & & & & & & Minimum & Peak probability & Maximum \\
\hline M03SM-1686 & 1 & WW4563 & Shell & 0 & 13,145 & 45 & $13,946 \mathrm{BC}$ & $13,600 \mathrm{BC}$ & $13,291 \mathrm{BC}$ \\
\hline M05IV-2365 & 2 & WW5360 & Charcoal & -25 & 525 & 35 & $1318 \mathrm{AD}$ & $1415 \mathrm{AD}$ & $1443 \mathrm{AD}$ \\
\hline PT1 Fossaria & 3 & WW4799 & Shell & 0 & 11,720 & 60 & 11,717 BC & $11,655 \mathrm{BC}$ & $11,470 \mathrm{BC}$ \\
\hline PT1 Pupillid & 3 & WW4800 & Shell & 0 & 12,110 & 140 & $12,608 \mathrm{BC}$ & $12,030 \mathrm{BC}$ & $11,711 \mathrm{BC}$ \\
\hline M06SM-163A1 & 4 & WW5717 & Shell & 0 & 415 & 35 & $1426 \mathrm{AD}$ & $1450 / 1605 \mathrm{AD}^{\mathrm{C}}$ & $1625 \mathrm{AD}$ \\
\hline M06SM-163A2 & 4 & WW5718 & Shell & 0 & 370 & 35 & $1446 \mathrm{AD}$ & $1487 / 1605 \mathrm{AD}^{\mathrm{C}}$ & $1634 \mathrm{AD}$ \\
\hline M06SM-163B2 & 4 & WW5725 & Charcoal & -25 & 65 & 45 & 1682 & $1715 / 1900 \mathrm{AD}^{\mathrm{c}}$ & $1955 \mathrm{AD}$ \\
\hline M06LA-428 & 5 & WW5715 & Shell & 0 & 295 & 40 & $1477 \mathrm{AD}$ & $1532 / 1640 \mathrm{AD}^{\mathrm{c}}$ & $1663 \mathrm{AD}$ \\
\hline
\end{tabular}

The quoted age is in radiocarbon years (BP) using the Libby half life of 5568 years.

a Values reported for $\delta{ }^{13} \mathrm{C}$ are the assumed values according to Stuiver and Polach (1977).

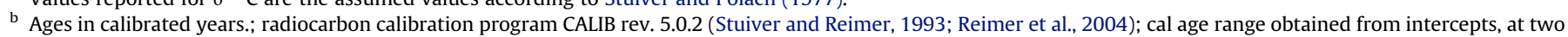
sigma.

c Normalized probability distribution using Reimer et al. (2004) is bimodal; peaks of two modes are given.

Radiocarbon dates are reported in calibrated years throughout this paper, unless specifically described otherwise. Dates for the late Holocene are reported in years $\mathrm{BC}$ and $\mathrm{AD}$ to facilitate comparisons with many other late Holocene records. Older dates that provide age control for alluvial fans are reported in calibrated years before present (BP), generally given in ka.

\subsection{Luminescence dating}

Samples were collected from freshly cleaned natural exposures or human-made pits for luminescence, water content, and doserate analysis as described by Mahan et al. (2007a), and Owen et al. (2007) using methods modified from Aitken (1985), Murray et al. (1987), and Snyder and Duval (2003). At least $50 \mathrm{~cm}$ of sediment was scraped or augered away from the face of each exposure before sampling for OSL dating to minimize the possibility of bleaching of the outer layers of the sediment by sunlight. Opaque plastic or steel tubes, $\sim 20 \mathrm{~cm}$-long, were hammered perpendicular into the exposed vertical faces to extract the sediment samples. The tubes were sealed and placed in light-proof photographic bags until the initial processing. Samples Cronese1 to Cronese3 were processed and measured at the luminescence laboratories at the University of Cincinnati and are listed in Löhrer (2008). The other samples were processed at the luminescence laboratory at the USGS in Denver, Colorado.

At least $5 \mathrm{~cm}$ of sediment was removed from both ends of the OSL sampling tube under safe light conditions in the luminescence laboratories. The ends and the middle portion of the samples were dried in an oven at $50{ }^{\circ} \mathrm{C}$. The dry ends (or bulk sediment samples) were crushed and homogenized and sent to the USGS Nuclear Reactor facility in Denver for neutron activation analysis (NAA) to determine radioisotope concentrations. The middle part was sieved to collect both fine $(<90 \mu \mathrm{m})$ and coarse grained fraction (with fractions between 90 and $250 \mu \mathrm{m}$ ). The $90-$ $125 \mu \mathrm{m}$ particle size fraction from the coarse grained fraction was leached in $10 \% \mathrm{HCl}$ for $24 \mathrm{~h}, 30 \% \mathrm{H}_{2} \mathrm{O}_{2}$ for $24 \mathrm{~h}$, and $10 \% \mathrm{HF}$ for $20 \mathrm{~min}$. The quartz fractions were separated using heavy liquids (lithium polytungstate). This was followed by a $49 \%$ HF leach for $40 \mathrm{~min}$ to etch the outer $10 \mu \mathrm{m}$ of each grain and then a leach in $10 \% \mathrm{HCl}$ for $2 \mathrm{~h}$. Steel target discs were sprayed with silica spray and a single grain thick layer of quartz grains was dispersed onto steel discs.

The discs for samples Cronese 1 to Cronese 3 were measured at the Luminescence Laboratory at the University of Cincinnati using a Riso TL/OSL reader (model DA-20). Luminescence from the quartz grains was stimulated using an array of blue-light emitting diodes $\left(470 \mathrm{~nm}, 50 \mathrm{~mW} / \mathrm{cm}^{2}\right.$ ) filtered using a green long-pass GG-420 filter. Detection was through a Hoya U-340 filter. All quartz aliquots were screened for feldspar contamination using infrared stimulation with infrared light emitting diodes $\left(870 \mathrm{~nm}, 150 \mathrm{~mW} / \mathrm{cm}^{2}\right)$. All OSL signals were detected using a $52 \mathrm{~mm}$ diameter photomultiplier tube $(9235 \mathrm{~B})$. The equivalent dose $\left(D_{\mathrm{e}}\right)$ measurements were determined on multiple aliquots using the single-aliquot regenerative (SAR) method protocol developed by Murray and Wintle (2000). Growth curve data was fitted using linear and exponential trend curves. The $D_{\mathrm{e}}$ value for every aliquot was examined using Riso Analysis 3.22b software. Between 20 and 60 aliquots were measured per sample. Aliquots with poor recuperation $(>10 \%)$ were not used in the age calculations. Equivalent doses of all aliquots were averaged for each sample then divided by the dose rate giving a mean age (Table 4). Calculation uncertainties and methods used to calculate dose rates are explained in the footnotes in Table 4.

Two types of luminescence dating were performed on different grain sizes and mineral fractions for samples run at the luminescence laboratory at the USGS in Denver. Blue-light OSL was performed on fine sand-size quartz separates. Infra-red OSL (IRSL, using infra-red stimulation of potassium-feldspars) was performed on a polymineralic fine silt fraction $(4-11 \mu \mathrm{m})$. All sand-size quartz samples were analyzed by single-aliquot regeneration (SAR) procedures (Murray and Wintle, 2000; Banerjee et al., 2001) with blue-light excitation. Dose recovery and preheat plateau tests were performed to ensure that the sediments were responsive to optical techniques and that the proper preheat temperatures were used in producing the equivalent dose $\left(D_{\mathrm{e}}\right)$ values. Fine-grained $(4-11 \mu \mathrm{m})$ polymineral extracts for IRSL were dated using the total-bleach multiple-aliquot additive-dose (MAAD) method (Singhvi et al., 1982; Lang, 1994; Richardson et al., 1997; Forman and Pierson, 2002). A minimum of two analyses per IRSL sample by MAAD methods was performed. Anomalous fading tests on the stability of the luminescence signal indicated little to no signal instability (recording ratios of $0.91-1.07$ ).

Cosmic-ray dose rate was estimated for each sample as a function of depth, elevation above sea level, and geomagnetic latitude (Prescott and Hutton, 1988). Volumetric saturation moisture was estimated by comparing volumes of packed dry sediment and thoroughly wetted sediment. This packing simulates the overburden compaction at the OSL sample site. The concentrations of $\mathrm{K}$, $\mathrm{U}, \mathrm{Th}$, and $\mathrm{Rb}$ were determined using NAA at the USGS Nuclear Reactor Facility in Denver following the procedures described in Budahn and Wandless (2002). Measured elemental concentrations, associated dose rates, and cosmic-ray contributions and NAA are presented in Table 4. The agreement between in situ and laboratory gamma-ray measurement as well as INAA results suggests negligible or no disequilibrium in the uranium and thorium dose-rate components. 
Table 4

Summary of OSL dating results for Mojave Desert sediment.

\begin{tabular}{|c|c|c|c|c|c|c|c|c|c|c|}
\hline $\begin{array}{l}\text { Sample } \\
\text { number }\end{array}$ & $\begin{array}{l}\text { Location } \\
\text { number }\end{array}$ & $\begin{array}{l}\text { Depth } \\
(\mathrm{cm})\end{array}$ & $\begin{array}{l}\mathrm{U}^{\mathrm{a}} \\
(\mathrm{ppm})\end{array}$ & $\begin{array}{l}\mathrm{Th}^{\mathrm{a}} \\
(\mathrm{ppm})\end{array}$ & $\begin{array}{l}\mathrm{K}^{\mathrm{a}} \\
(\%)\end{array}$ & $\begin{array}{l}\text { Cosmic }^{\mathrm{b}, \mathrm{c}} \\
\left(\mathrm{mGya}^{-1}\right)\end{array}$ & $\begin{array}{l}\text { Dose-rate }{ }^{\mathrm{b}, \mathrm{d}} \\
\left(\mathrm{mGya}^{-1}\right)\end{array}$ & $\mathrm{N}^{\mathrm{e}}$ & $\begin{array}{l}\text { Mean } D_{\mathrm{E}}{ }^{\mathrm{f}} \\
(\mathrm{Gy})\end{array}$ & $\begin{array}{l}\text { Age }^{g} \\
\text { (ka) }\end{array}$ \\
\hline Cronese 1 & 4 & 23 & 1.60 & 5.98 & 2.29 & $0.22 \pm 0.02$ & $2.91 \pm 0.19$ & $22(22)$ & $1.10 \pm 0.10$ & $\begin{array}{c}\mathbf{0 . 3 6} \pm \mathbf{0 . 0 4} \\
0.23 \pm 0.10 \\
0.27 \pm 0.08\end{array}$ \\
\hline Cronese2 & 4 & 65 & 3.88 & 8.76 & 2.44 & $0.21 \pm 0.02$ & $3.71 \pm 0.23$ & $21(22)$ & $1.80 \pm 0.01$ & $\begin{array}{l}\mathbf{0 . 4 9} \pm \mathbf{0 . 1 0} \\
0.39 \pm 0.08 \\
0.41 \pm 0.04\end{array}$ \\
\hline Cronese3 & 4 & 210 & 1.69 & 5.74 & 2.15 & $0.17 \pm 0.02$ & $2.75 \pm 0.18$ & $17(22)$ & $0.98 \pm 0.20$ & $\begin{array}{l}\mathbf{0 . 3 5} \pm \mathbf{0 . 0 1} \\
0.27 \pm 0.03 \\
0.30 \pm 0.04\end{array}$ \\
\hline M05CL-19 & 6 & 115 & $3.25 \pm 0.09$ & $6.73 \pm 0.29$ & $1.91 \pm 0.07$ & $0.22 \pm 0.02$ & $3.94 \pm 0.09$ & $22(25)$ & $41.8 \pm 1.41$ & $10.6 \pm 0.56$ \\
\hline M02VI-989 & 7 & 50 & $1.87 \pm 0.12$ & $9.89 \pm 0.29$ & $2.22 \pm 0.02$ & $0.21 \pm 0.02$ & $5.31 \pm 0.11$ & $40(40)$ & $50.1 \pm 1.78$ & $\begin{array}{l}10.6 \pm 0.56(\text { IRSL) } \\
11.8 \pm 0.56\end{array}$ \\
\hline M02VI-990 & 7 & 30 & $2.54 \pm 0.15$ & $13.7 \pm 0.34$ & $2.68 \pm 0.02$ & $0.23 \pm 0.02$ & $5.59 \pm 0.07$ & $34(34)$ & $43.3 \pm 2.17$ & $\begin{array}{l}9.44 \pm 0.49 \text { (IRSL) } \\
8.31 \pm 0.51 \text { (IRSL) } \\
7.74 \pm 0.54\end{array}$ \\
\hline B02AM-391A & 3 & 25 & $2.99 \pm 0.16$ & $12.1 \pm 0.33$ & $2.34 \pm 0.02$ & $0.24 \pm 0.02$ & $3.48 \pm 0.05$ & $29(30)$ & $35.1 \pm 1.07$ & $\begin{array}{l}10.1 \pm 0.53 \\
9.46 \pm 0.26(\text { IRSL) } \\
11.1 \pm 0.31 \text { (IRSL) }\end{array}$ \\
\hline B02AM-391B & 3 & 50 & $2.99 \pm 0.17$ & $13.2 \pm 0.46$ & $2.70 \pm 0.03$ & $0.21 \pm 0.02$ & $4.90 \pm 0.06$ & & $\begin{array}{l}50.2 \pm 0.78 \\
55.0 \pm 0.92\end{array}$ & $\begin{array}{l}10.2 \pm 0.42 \text { (IRSL) } \\
10.8 \pm 0.47 \text { (IRSL) }\end{array}$ \\
\hline В02АМ-393 & 8 & 50 & $2.04 \pm 0.12$ & $12.1 \pm 0.26$ & $3.41 \pm 0.03$ & $0.21 \pm 0.02$ & $5.82 \pm 0.05$ & & $\begin{array}{l}61.8 \pm 0.56 \\
64.8 \pm 0.71\end{array}$ & $\begin{array}{l}10.6 \pm 0.26 \text { (IRSL) } \\
11.1 \pm 0.30 \text { (IRSL) }\end{array}$ \\
\hline B02AM-394 & 8 & 50 & $2.07 \pm 0.12$ & $11.1 \pm 0.30$ & $3.16 \pm 0.02$ & $0.21 \pm 0.02$ & $4.76 \pm 0.05$ & $29(30)$ & $64.8 \pm 0.71$ & $12.1 \pm 0.77$ \\
\hline M05AM-28 & 3 & 25 & $2.20 \pm 0.11$ & $9.35 \pm 0.28$ & $2.47 \pm 0.06$ & $0.24 \pm 0.02$ & $3.26 \pm 0.07$ & $24(26)$ & $30.5 \pm 0.92$ & $9.4 \pm 0.67$ \\
\hline JY99-55 & 9 & 45 & 2.03 & 3.86 & 2.52 & $0.25 \pm 0.02$ & $0.25 \pm 0.02$ & & & $13.3 \pm 0.68($ IRSL $)$ \\
\hline JY99-56 & 9 & 125 & 2.35 & 5.41 & 2.47 & $0.23 \pm 0.01$ & $0.23 \pm 0.01$ & & & $13.9 \pm 0.79($ IRSL) \\
\hline KS04-IV-33 & 2 & 115 & 1.43 & 12.7 & 3.76 & $0.18 \pm 0.02$ & $0.18 \pm 0.02$ & $7(8)$ & $28.0 \pm 1.15$ & $5.52 \pm 0.54$ \\
\hline
\end{tabular}

${ }^{a}$ Elemental concentrations from NAA of whole sediment were measured at the USGS TRIGA Reactor in Denver. Uncertainty taken as $\pm 10 \%$ if errors are not shown.

b Cosmic dose rate estimated fractional water content from whole sediment (Aitken, 1998). Uncertainty taken as $10 \pm 5 \%$.

c Estimated contribution to dose-rate from cosmic rays calculated according to Prescott and Hutton (1994). Uncertainty taken as $\pm 10 \%$.

d Total dose rate from beta, gamma and cosmic components. Beta attenuation factors for U, Th and K compositions incorporating grain size factors from Mejdahl (1979). Beta

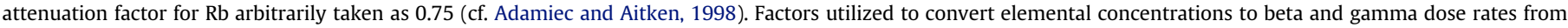
Adamiec and Aitken (1998) and beta and gamma components attenuated for moisture content.

e Number of replicated $D_{\mathrm{e}}$ estimates used to calculate mean $D_{\mathrm{e}}$. The number in parenthesis is the total number of aliquots measured. These are based on recuperation error of $<10 \%$.

${ }^{\mathrm{f}}$ Mean equivalent dose $\left(D_{\mathrm{e}}\right)$ determined from replicated single-aliquot regenerative-dose (SAR; Murray and Wintle, 2000) runs. Errors are 1-sigma incorporating error from beta source estimated at about $\pm 5 \%$.

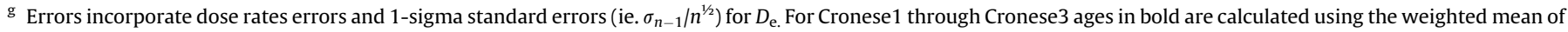
all the aliquots and can be considered as maximum ages. Ages in italics use lowest $10 \%$ of the aliquots and ages in plain text use the lowest $20 \%$ of the aliquots.

\section{Present Mojave Desert climate}

The Mojave Desert occupies a position of low elevation between the Transverse Ranges and the Sierra Nevada on the west and the Colorado Plateau on the east. It grades southward into lower elevation Sonoran Desert and northward into higher elevation Great Basin Desert (Fig. 1). Of the several studies describing aspects of the climatology of the Mojave Desert, only Hereford et al. (2006) comprehensively treated the historic patterns. Most of this summary is drawn from that paper.

The Mojave Desert is arid to semi arid, historically receiving $\sim 140 \mathrm{~mm}$ of mean annual precipitation, largely due to winter storms, despite the rain shadow provided by the Sierra Nevada and Transverse Ranges. It experiences cool winters and hot summers. May and June are low-precipitation months, and provide a basis for dividing the year into warm-season (July 4-October 14; mean annual precipitation $35 \mathrm{~mm}$ ) and cool-season (October 15-April 15; mean annual precipitation $95 \mathrm{~mm}$ ) precipitation patterns. The western Mojave Desert, roughly the area west of $117^{\circ}$ latitude, receives cool-season dominant precipitation, whereas the eastern Mojave Desert receives an increasing proportion of warm-season precipitation, up to about $30 \%$.

The historical record of Mojave Desert climate is related to large-scale changes in Pacific Ocean sea-surface temperature (SST) caused by El Niño-Southern Oscillation (ENSO) and Pacific Decadal Oscillation (PDO) forcings (Cayan et al., 1998, 1999). El Niño events tend to correspond to wet winters in the American Southwest.
Major cool-season storms are extratropical cyclones of the North Pacific Ocean that are associated with synoptic tropospheric depressions that drive a southward expansion of the Aleutian low pressure center. Cool-season storms produce long-duration, widespread, low-intensity precipitation. Higher mountains experience significant snowfall. In contrast, warm-season storms are an extension of the North American monsoon, a seasonal reversal of circulation that transports maritime tropical moisture in convective storms from the Gulf of California. Warm-season storms are convective and provide brief, local, and commonly intense rainfall. Infrequently occurring tropical cyclones and hurricanes form in the tropical Pacific Ocean during the fall (Hereford et al., 2006).

Prehistoric Holocene paleoclimate of the Mojave Desert is poorly known owing to sparse pack-rat midden, dendrochronology, and paleohydrology data. Plant communities similar to those of the Pleistocene full glacial period persisted until $\sim 11 \mathrm{ka}$, after which less dramatic changes occurred (Koehler et al., 2005). Pleistocene vegetation such as singleleaf pinyon pine (Pinus monophylla), California juniper (Juniperus californica), and Joshua tree (Yucca brevifolia) persisted at low elevations until $\sim 13.5 \mathrm{ka}$, after which pinyon receded and sagebrush (Artemisia spp.) entered during a continued cool and wet assemblage. About $8.7 \mathrm{ka}$, a plant assemblage including bursage (Ambrosia dumosa), creosote bush (Larrea tridentata), Mojave sage (Salvia mohavensis), and Mormon tea (Ephedra spp.) colonized most lowlands, indicating much drier and warmer conditions. 


\section{Results}

\subsection{Radiocarbon ages}

\subsubsection{Radiocarbon reservoir corrections}

Radiocarbon reservoir effects may be important for lake and wetland dates on aquatic fauna. Effects for wetland environments were minimized by dating semi-aquatic and terrestrial snails, following the methods of Pigati et al. (2004). Because all considerations of radiocarbon ages on aquatic fauna depend on this correction, the reservoir effect is evaluated here, and then applied in all ensuing sections of this paper.

Two studies have evaluated radiocarbon reservoir for the Mojave River and its terminal lakes, and data in Tables 2 and 3 offer a third evaluation. Mollusks from the Mojave River system were ascribed a reservoir effect of 350 years by Berger and Meek (1992), which was modified to $310 \pm 60$ years by Culleton (2006). However, this Mojave River analysis is limited in applicability because it used archived shells from two separate river systems in order to obtain sufficient carbon, leaving questions as to its applicability to the Mojave River. Later, Owen et al. (2007) concluded that the reservoir effect in the Mojave River system is $<150$ years by dating adjacent shell and charcoal from late Holocene human middens. The three shell ages by Owen et al. (2007) are given in Table 5 (AP13A, AP14A, AP15A) along with the paired charcoal ages (AP13B, AP14B, AP15B). Three shell ages are quite similar, and may represent a single-lake event, and on this basis we combined the data to arrive at a combined age and standard error of $820 \pm 25$ years. The charcoal used in roasting fires consists of large chunks that probably represent wood transported by the Mojave River, since mostly small shrubs inhabit the area around the lake. This observation raises the possibility that the wood is older than the flood event that transported it to the lake. Two charcoal dates are similar (AP13B, AP14B) and give a combined age of $680 \pm 30$ years. The remaining age is older (AP15B) and possibly represents older wood. If all three charcoal ages are combined they yield an age of $730 \pm 25$ years. These two interpretations result in reservoir corrections of either 140 years (two charcoal dates) or 90 years (three charcoal dates).

As will be described below, shells were dated at another location in Cronese Lake and compared to the ages to OSL ages on immediately underlying lacustrine sand. The 140-year correction yields the best fit to the OSL ages. For this reason, a 140-year radiocarbon reservoir correction is used for late Holocene aquatic fauna in the Mojave River system. Reservoirs are not calibrated for other fluvial and lake systems, and for those no correction is applied.

\subsubsection{Radiocarbon results}

Shells and charcoal were dated in several settings of lacustrine and wetland environments that provide information either on ages for adjacent alluvial fan deposits or for river and lake history. Samples from locations 1-3 presented in Table 3 provide constraints on the ages of the alluvial fan unit Qya4 (described in Table 1), which is a widespread unit in the Mojave Desert that has been noted by several workers as bracketing the PleistoceneHolocene transition. The youngest part of unit Qya4 overlies groundwater-discharge deposits (GWD) at location 1 and lacustrine sediments at location 3 . In both sites, shells dated by radiocarbon are between 15.6 and $13.4 \mathrm{cal}$ ka BP (Table 3). Charcoal at Tough Nut Wash from a midden overlying unit Qya4 is an outlier, giving a Little Ice Age (LIA) date of $525 \pm 35{ }^{14} \mathrm{C}$ BP, which calibrates to between AD 1318 and 1443 (location 2, Table 3).

Samples from locations 4-5 (Table 3 ) define the ages of lacustrine deposits ringing modern playas, all yielding ages consistent with an LIA interpretation. At location 4, Anodonta californiensis (S. Sharpe, written communication, 2009) shells in growth position were collected from a thin sand bed at the crest of a beach or wavecut bench. Charcoal also collected at this location could not be shown in the field to be part of the deposit, other possibilities being that it was wind- or water-transported more recently to this surface. The charcoal was collected, however, to evaluate for freshwater radiocarbon reservoir effects. The Anodonta shells yielded similar ${ }^{14} \mathrm{C}$ ages that calibrate to nearly identical LIA ages. As the shells were growing in the same sand bed, the ages were combined

Table 5

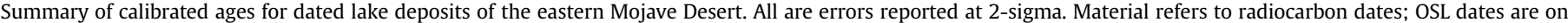
quartz.

\begin{tabular}{|c|c|c|c|c|c|c|c|}
\hline Sample Number & Location & Reference & Material & Age & Cal max & Cal peak & Cal min \\
\hline AP13A & E. Cronese Lake & Owen et al., 2007 & Shell & $810 \pm 40$ & $1160 \mathrm{AD}$ & 1222 & $1277 \mathrm{AD}$ \\
\hline AP13B & E. Cronese Lake & Owen et al., 2007 & Charcoal & $710 \pm 50$ & $1219 \mathrm{AD}$ & 1280 & $1392 \mathrm{AD}$ \\
\hline AP14A & E. Cronese Lake & Owen et al., 2007 & Shell & $850 \pm 50$ & $1043 \mathrm{AD}$ & 1212 & $1269 \mathrm{AD}$ \\
\hline AP14B & E. Cronese Lake & Owen et al., 2007 & Charcoal & $660 \pm 40$ & $1041 \mathrm{AD}$ & $1294 / 1374$ & $1397 \mathrm{AD}$ \\
\hline AP15A & E. Cronese Lake & Owen et al., 2007 & Shell & $810 \pm 40$ & $1160 \mathrm{AD}$ & 1222 & $1277 \mathrm{AD}$ \\
\hline AP15B & E. Cronese Lake & Owen et al., 2007 & Charcoal & $860 \pm 50$ & $1041 \mathrm{AD}$ & 1190 & $1263 \mathrm{AD}$ \\
\hline Beta 25634 & Silver Lake & Owen et al., 2007 & Bulk C & $390 \pm 90$ & $1325 \mathrm{AD}$ & $1460 / 1605$ & $1950 \mathrm{AD}$ \\
\hline Beta 25341 & Silver Lake & Enzel et al., 1989 & Bulk C & $3620 \pm 70$ & 2197 BC & -1975 & $1772 \mathrm{BC}$ \\
\hline Cronese 1 & E. Cronese Lake & Drover, 1978 & Bulk C & $3500 \pm 180$ & 2339 BC & -1850 & $1415 \mathrm{BC}$ \\
\hline Cronese 2 & E. Cronese Lake & Drover, 1978 & Charcoal & $560 \pm 110$ & $1229 \mathrm{AD}$ & $1335 / 1405$ & $1632 \mathrm{AD}$ \\
\hline Cronese 3 & E. Cronese Lake & Drover, 1978 & Shell & $1190 \pm 90$ & $666 \mathrm{AD}$ & 840 & $1012 \mathrm{AD}$ \\
\hline Cronese 4 & W. Cronese Lake & Drover, 1978 & Charcoal & $390 \pm 140$ & $1293 \mathrm{AD}$ & $1450 / 1610$ & $1952 \mathrm{AD}$ \\
\hline M06LA-428 & Rosamond Lake & This paper & Shell & $295 \pm 40$ & $1477 \mathrm{AD}$ & $1532 / 1640$ & $1663 \mathrm{AD}$ \\
\hline M06SM-163A1 & E.Cronese Lake & This paper & Shell & $415 \pm 35$ & $1426 \mathrm{AD}$ & 1450 & $1625 \mathrm{AD}$ \\
\hline M06SM-163A2 & E.Cronese Lake & This paper & Shell & $370 \pm 35$ & $1446 \mathrm{AD}$ & 1487 & $1634 \mathrm{AD}$ \\
\hline M99VJ-988 & Silurian Lake & Mahan et al., 2007a & OSL & $925 \pm 229$ & $846 \mathrm{AD}$ & 1075 & $1304 \mathrm{AD}$ \\
\hline M01OM-1844 & Silurian Lake & Mahan et al., 2007a & OSL & $733 \pm 119$ & $1148 \mathrm{AD}$ & 1267 & $1386 \mathrm{AD}$ \\
\hline M01OM-1844 & Silurian Lake & Mahan et al., 2007a & OSL & $953 \pm 206$ & $841 \mathrm{AD}$ & 1047 & $1253 \mathrm{AD}$ \\
\hline Cronese1 & E. Cronese Lake & This paper & OSL & $360 \pm 40$ & $1605 \mathrm{AD}$ & 1645 & $1685 \mathrm{AD}$ \\
\hline Cronese2 & E. Cronese Lake & This paper & OSL & $490 \pm 100$ & $1415 \mathrm{AD}$ & 1515 & $1615 \mathrm{AD}$ \\
\hline Cronese3 & E. Cronese Lake & This paper & OSL & $350 \pm 10$ & $1645 \mathrm{AD}$ & 1655 & $1665 \mathrm{AD}$ \\
\hline \multicolumn{8}{|l|}{ Combined data } \\
\hline 3 Cronese MWP shell & E. Cronese Lake & Owen et al., 2007 & Shell & $820 \pm 25$ & $1173 \mathrm{AD}$ & 1220 & $1264 \mathrm{AD}$ \\
\hline 3 Cronese charcoal & E. Cronese Lake & Owen et al., 2007 & Charcoal & $730 \pm 27$ & $1228 \mathrm{AD}$ & 1277 & $1295 \mathrm{AD}$ \\
\hline 2 Cronese LIA shells & E. Cronese Lake & This paper & Shell & $393 \pm 25$ & $1441 \mathrm{AD}$ & 1655 & $1621 \mathrm{AD}$ \\
\hline 3 Silurian OSL & Silurian Lake & Mahan et al., 2007a & OSL & $815 \pm 110$ & $1075 \mathrm{AD}$ & 1185 & $1295 \mathrm{AD}$ \\
\hline
\end{tabular}


to arrive at a mean ${ }^{14} \mathrm{C}$ age of $393 \mathrm{BP}$ with a weighted error of \pm 25 years. When the reservoir correction is applied, the age for shells at location 4 is $250 \pm 25$ years BP, which calibrates to between AD 1526 and 1951, with a strong mode at AD 1655. This age may overlap with the age for the charcoal, which probably is modern. Location 5 represents thin lacustrine sand near the margin of Rosamond (dry) Lake, where mollusks of an unknown species were collected from a bed set into eroded Pleistocene sands and gravels. The new radiocarbon ages provide additional age control for late Holocene lakes, which was used to test climate and landscape response models.

\subsection{Luminescence ages}

Two luminescence samples (B02AM-393, B02AM-394) were collected near the town of Essex in Fenner Wash (location 8, Fig. 2). Distal alluvial fan deposits with soils similar to those for unit Qia1 of Bedford (2003) occupy the broad center of Fenner Valley. Set within these deposits are Qya4 fluvial fill terraces that grade to Qya4 fan deposits in many locations (Bedford et al., 2006). One sample was collected from each of these deposits. OSL ages (Table 4) for these samples are consistent with inset relations, but ages for the presumed Pleistocene deposits are younger than expected. The young age may owe to young silt from illuvial fines (Bedford et al., 2006) or to misidentification of an early Qya4 fan deposit due to unusual soils.

Two luminescence samples (B02AM-391A, B02AM-391B) were collected from a vertical section of trench dug into GWD near the town of Chambless (location 3). These deposits consist of calciumcarbonate-rich sand and silt capped by a resistant carbonate 'hardground' and a thin mantle of Qya4 gravel and sand. The age data in Table 4 are stratigraphically consistent, and suggest that the deposits are about 11-10 ka. One luminescence sample (M05AM28) was collected in GWD farther south in the Chambless GWD complex at a site where aquatic and semi-aquatic shells were dated by radiocarbon methods. Deposits at this site are similar in age to deposits farther north. Another GWD complex in the eastern Mojave Desert at Kelso Wash that is overlain by alluvial fan unit Qya4 was sampled in a vertical profile (samples JY99-55 and -56, location 9). IRSL ages for these samples, at 14-13 ka, are somewhat older than the Chambless GWD ages.

A sample in a GWD complex at Grassy Valley north of Barstow (location 6), which underlies distal Qya4 fan deposits (M05CL-19), yielded a quartz OSL age of $10.6 \pm 0.6 \mathrm{ka}$, demonstrating that GWD and overlying Qya4 deposits are approximately the same age in the central and eastern Mojave Desert.

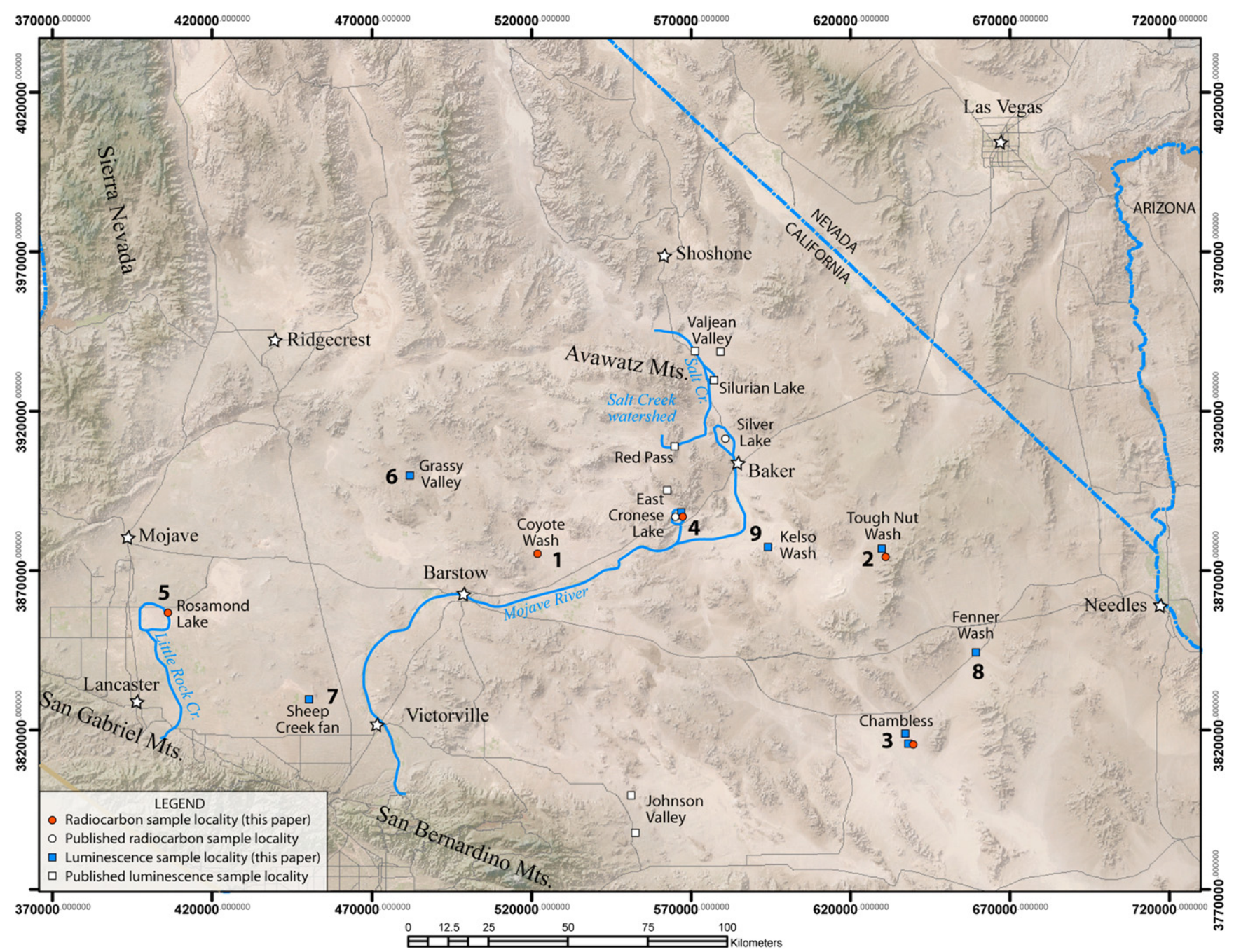

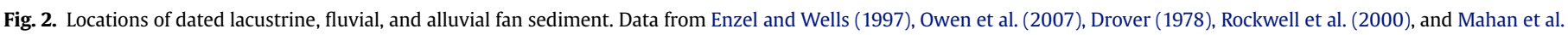
(2007a) are indicated by white symbols; data reported in this paper by colored symbols at numbered locations. 
Basal sediments were dated within an active wash high in a fan near Tough Nut Wash (location 2, Fig. 2) in the Providence Mountains (Stock et al., 2007) to determine the timing for first sands deposited on a buried lower soil. The age of $5.5 \mathrm{ka}$ (KS04-IV-33) is hard to interpret for fan deposition in this area because it lies under an active wash, but is consistent with ages for other Qya3 deposits.

An unusual fan built of fine-grained materials issuing from the San Gabriel Mountains as mudflows was sampled for OSL. The Sheep Creek fan (location 7, Fig. 2) was dated at its terminus where it exhibits a thick sequence of fine-grained muddy sand units with several weak soils in the $\sim 10$-m-thick section. The OSL ages (M02VI-989 and -990) indicate that it ranges from 11 to $8 \mathrm{ka}$, as a minimum time span.

Three OSL samples (Cronese1-Cronese3) were collected from lake sediments in East Cronese Lake Basin (Löhrer, 2008). These samples were young (a few hundred years old) and as such any partially bleached grains will have a significant effect on the ages of the sample, providing over-estimates of the true age. To examine this more carefully, OSL ages are presented based on the weighted mean of the equivalent doses for all the aliquots that can be considered as maximum ages, and the lowest $20 \%$ and lowest $10 \%$ of the equivalent doses of the aliquots that more likely reflect the true age of the samples (Table 4). Despite which method is used to determine the age, the samples show that the sediments likely formed during the LIA.

\section{Interpretation}

\subsection{River and lake records}

Table 5 is a summary of dated Holocene lake deposits, which fall into three age groups: the Neoglacial at about 1900 BC; a period within the latter part of the Medieval Warm Period (MWP); and the LIA. These deposits are critically examined in the following paragraphs.

Holocene lake sediments were dated by Drover (1978) at East Cronese Lake $\left(3500 \pm 180{ }^{14} \mathrm{C} \mathrm{BP}\right)$ and by Enzel and Wells (1997) at Silver Lake $\left(3620 \pm 70{ }^{14} \mathrm{C} \mathrm{BP}\right)$. These ages correspond to calibrated ranges of $\sim 2300$ to $\sim 1400 \mathrm{BC}$ (Table 5). Enzel and Wells (1997) attributed the lakes to the Neoglacial, a period of ice advance in the western US, and numerous floods in the southwest (Ely et al., 1993).
Lake deposits from the MWP were verified at East Cronese Lake by dating material from pairs of shells and charcoal sampled in three middens (Owen et al., 2007). The ages demonstrated that one or more lakes persisted at $\sim 810 \pm 40{ }^{14} \mathrm{C}$ BP (Table 5). After adjusting for a radiocarbon reservoir effect, the calibrated age range (Table 5) is AD 1270-1385, with a broad peak centered on $\sim A D$ 1290 (Fig. 4).

The only MWP lake deposit dated outside of the rivers flowing from the Transverse Ranges was studied by Mahan et al. (2007a) at Silurian Lake (Fig. 2), which is fed by Salt Creek. Although the Mojave River caused Lake Mojave to spillover into this part of Salt Creek during the Pleistocene (Wells et al., 2003), spillover ceased before $\sim 10 \mathrm{ka}$ (Mahan et al., 2007b). Three IRSL dates from two samples (Table 5) taken in a broad, little-dissected spit at Silurian Lake yielded a combined age of AD $1185 \pm 110$, which is similar to the East Cronese MWP lake timing but could represent an earlier lake. Together, these two chronologic data sets point to rivers and streams flowing persistently in both internal desert drainages as well as rivers sourced from the Transverse Ranges during the AD 1280-1290 time interval.

LIA lake deposits associated with the Mojave River system were dated by radiocarbon on charcoal collected at a shoreline by Drover (1978) at East Cronese Lake and on dispersed organics in cores by Enzel and Wells (1997) at Silver Lake (Table 5). The new shoreline sediment ages on shells from East Cronese Lake are very similar to previous ages at about $390{ }^{14} \mathrm{C} \mathrm{BP}$. All of these ages calibrate as a bimodal probability distribution, with peaks centered on $\sim A D$ 1460 and $\sim 1605$. The pair of shells collected in growth position at the shorezone landform provided a calibrated and reservoir-corrected age of $\sim$ AD 1660 . Calibrated shell ages were tested by dating underlying sands using OSL (Fig. 3), but the results were inconsistent with depth unless they are interpreted as representing rapid deposition at $\sim$ AD 1640-1650. Although multiple interpretations are involved in this analysis, the correspondence of the OSL results and the reservoir-corrected radiocarbon data (Fig. 4) affirms a conclusion that LIA lakes at Cronese existed at $\sim \mathrm{AD} 1650$. Discrepancies between OSL and radiocarbon dates on shells were noted for Silver Lake sediments (Owen et al., 2007), but in this case the radiocarbon results were much older than the OSL ages.

The LIA mollusks at Rosamond Lake provide evidence that other major streams (Little Rock Creek, Fig. 2) sourced in the Transverse
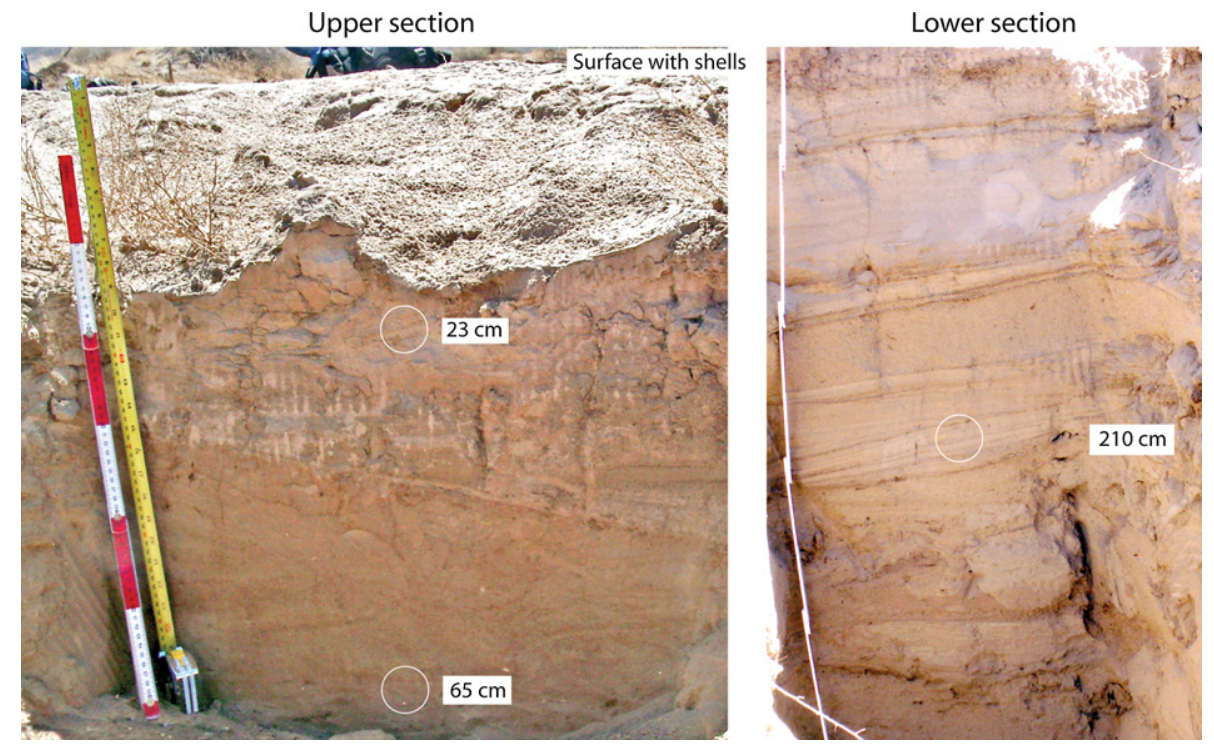

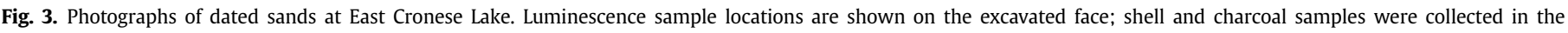
uppermost layer. 


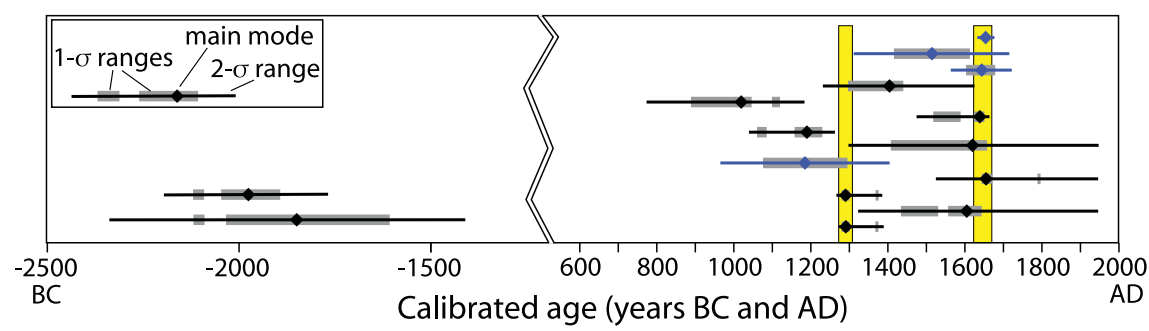

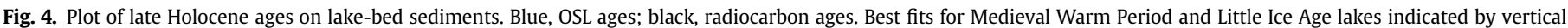

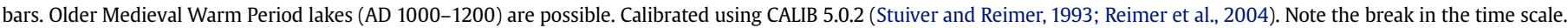

Ranges formed lakes during the LIA. The timing at Rosamond Lake has peak probabilities centered on $\sim$ AD 1480 and $\sim 1665$, and thus is similar to timing at East Cronese and Silver lakes. It is possible that a reservoir effect requires an adjustment in the Little Rock Creek system but the authors have no basis for doing so; magnitude of correction is unknown for Rosamond Lake. The combined lake records demonstrate that during the LIA, multiple streams from the Transverse Ranges were persistent enough to create definable terminal lake deposits and support aquatic life. If all dates are required to represent a single LIA lake event, the single consistent period for LIA lakes is $\sim A D 1650$, which satisfies the ages from OSL, reservoir-corrected shells in the Mojave River system, organic matter, and uncorrected shells in the Little Rock Creek system (Fig. 4). Although not a unique interpretation, this single-lake period result is the simplest interpretation.

\subsection{Alluvial fan records}

Until recently, dating of alluvial fans in the Mojave Desert area has been limited to places where fans interact with valley-floor deposits dateable by radiocarbon (Reheis et al., 1989, 1996; Bell et al., 1999; Wells et al., 2003) and to a few fans with interbedded eolian sand dated by OSL (McDonald and McFadden, 1994). Thermoluminescence dating at the Nevada Test Site (NTS) generally provided maximum ages for alluvial fans, but many dates were on targets specific to earthquake hazard investigations rather than alluvial fan stratigraphic units, and the method provided imprecise ages (Keefer et al., 2004). More recently, OSL dating of fine-grained sediment entrained within the fans has expanded the available ages by an order of magnitude (Rockwell et al., 2000; Mahan et al. 2007a,b; Sohn et al., 2007), and several additional new ages on fans are reported (Table 4 ).

The summary of dated fan deposits (Fig. 5) shows two peaks in age distribution, one from about 13-9 ka (unit Qya4 deposits) and one at 6-3 ka (unit Qya3 deposits). Several radiocarbon dates shown in Fig. 5 represent limiting ages, such as lake and GWD sediments that are overlain by unit Qya4 fan deposits. As such, the range of dates may emphasize the limits of the age range, but nonetheless probably provides a good approximation of the depositional ages of these fan deposits. TL ages are distinguished from NTS because they have errors greater than $10 \%$, allowing them to lie within adjacent bins on the histogram, and the values at 9-7 ka are interpreted as outliers until more supporting data are acquired.

The age ranges are similar to sets of dates for the southern Great Basin (Reheis et al., 1996) and the Transverse Ranges (McFadden and Weldon, 1987), but in both of those places many or all of the deposits were dated in low areas where they interfinger with marshy deposits. In both places, a few dates lie between the two distinct groups considered to represent unit Qya3 and unit Qya4 deposits for the Mojave Desert. More geochronological data from the Mojave Desert deposits may demonstrate a continuum in ages, but at this time the dates are interpreted as supporting two pulses of alluvial fan aggradation separated by a lull in deposition.

\subsection{Hybrid environments}

The distinction between alluvial fan deposits and axial-valley wash deposits is not always clear, and thus this section addresses possible hybrid environments. The view of the desert geomorphic systems is that alluvial fan sedimentation leads to deposition in the distal areas, where it interacts with through-going axial-valley stream systems to cause aggradation. The general observation from geologic mapping is that surfaces and deposits of alluvial fans are concordant with axial-valley wash deposits, suggesting that depositional events in the major washes are primarily in synchrony with alluvial fan deposition. However, the major washes also experience significant stream flow during events that lead to lake filling, during which aggradation may occur, and therefore may have hybrid signatures. For this reason, axial-valley wash deposits are examined as a separate age record.

Axial-valley washes were dated in Dumont basin by K.C. Anderson and S.G. Wells (2003) using radiocarbon methods on charcoal and wetland organic deposits (black mats). These yielded one early Holocene age and several late Holocene ages. Farther upstream in the same valley, Salt Creek Wash deposits that interfinger with adjacent alluvial fan deposits (Miller et al., 2007), were dated by Mahan et al. (2007a) as having been deposited between $6 \mathrm{ka}$ and $5 \mathrm{ka}$. The dates in Fenner Wash were between $12 \mathrm{ka}$ and $10 \mathrm{ka}$ in age (Table 4).

Interfingering of alluvial fan deposits with GWD might be considered as another hybrid environment, since in most cases these sites represent distal fan settings. Most GWD appear to represent times of high water tables, rather than depositional events on the piedmont, and as a result are not very informative for interpreting fan deposition. However, the stratigraphic association of alluvial fan deposits lying on GWD accurately represents timing of distal fan deposition.

One special alluvial fan case is the Sheep Creek fan (Fig. 2), where snowmelt-enhanced mudflows build the alluvial fan (Morton and Campbell, 1974). The distal Sheep Creek fan exhibits a thick sequence of fine-grained muddy sand units with several weak soils in the $\sim 10$-m-thick exposure. The OSL ages indicate a minimum age range of $11-8 \mathrm{ka}$, a time span that is wider than that for other alluvial fans. This location may be unique in that the fan is built by cool-season storm activity.

Axial-valley wash sediments, where traceable to concordant alluvial fans, are synchronous with fan deposition and we include these in the fan ages shown in Fig. 5. Arroyo-fill and in-stream GWD may be discordant with fan deposition, instead capturing times of flooding and high GW tables. The timing of activity on Sheep Creek fan may be discordant with other fans because of demonstrated winter-season deposition (Morton and Campbell, 1974). The latter two types of hybrid deposits are not included in Fig. 5. 


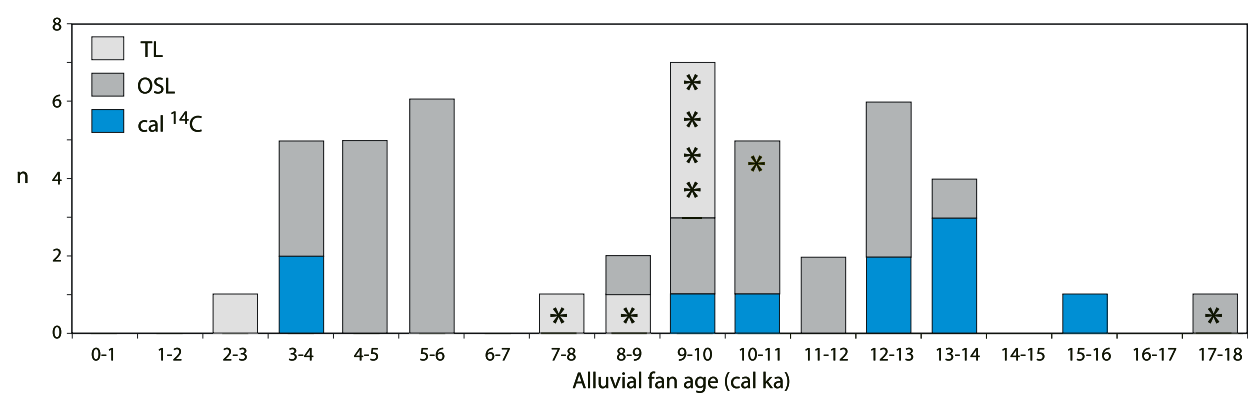

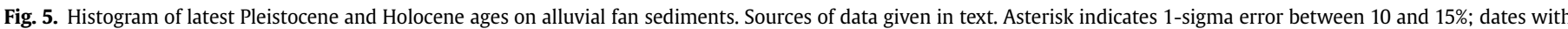
errors greater than $15 \%$ not included.

\section{Discussion}

\subsection{Correlations with climate records}

Climate records are generally sparse for the Mojave Desert but available records should help with interpreting data analyzed by this study. In particular, tree-ring reconstructions of wet periods and drought, along with paleontologic records from nearby marine settings, provide informative comparisons. North of the Mojave Desert, records of drought, floods, and high-lake stands for several terminal basins fed by eastern Sierra Nevada watersheds may be informative, but potentially these hydrologic systems are out of phase with the Mojave Desert. Several lakes west of the principal coastal ranges that cause rain shadow have been studied but most have low resolution for the times that Mojave lakes were present; the Negrini et al. (2006) record at Tulare Lake is an exception.

\subsubsection{Rivers and lakes}

7.1.1.1. Medieval Warm Period. The results point to late MWP lakes at $\sim$ AD 1280-1300 but if radiocarbon reservoir effects of 90 years are not considered, the lakes are $\sim$ AD 1215-1255. The occurrence of deep lakes is inconsistent in general with the fact that the MWP represented a prolonged warm period known for several extended droughts (e.g., Stine, 1994; Cook et al., 2004; MacDonald, 2007; Meko et al., 2007) in the western US. However, periods of enhanced river flow and lake rises are also known for the MWP (Ely et al., 1993; Stine, 1994; Adams, 2003, 2007).

Tree-ring records for the Transverse Ranges (MacDonald, 2007) can be interpreted as representing wetter cool-season conditions during $\sim$ AD 1080-1120, 1170-1205, and 1240-1290. The last period lends support to the interpretation of the formation of Mojave Desert lakes. The dendrochronology compilation used to interpret past drought severity by Cook and Krusic (2004) shows a period of wetter than usual years from AD 1298 to 1335 for the Mojave Desert region. Santa Barbara channel SST proxy data point to a wet period $\sim$ AD 1280 (Kennett and Kennett, 2000) and bristlecone pine records indicate a similar timing of cool conditions $\sim$ AD 1240 (Hughes and Graumlich, 2000; Salzer and Hughes, 2007). The rise of the last deep Tulare Lake started at about this same time (Negrini et al., 2006). In general, there seems to be climatic evidence for wetter and cooler conditions within a few decades of AD 1290.

However, Sierra Nevada records are generally disjunct with Mojave Desert records. The Graumlich (1993) interpretation of the southern Sierra Nevada tree-ring records indicated MWP wet periods $\sim$ AD 1070-1200 and 1215-1250. Stine's (1994) records for Mono Lake and the Walker River megadroughts brackets the intervening wetter period to $\sim A D$ 1100-1200 and indicates that drought extended from AD 1200 to 1350. Records for Walker Lake and Carson Lake (Adams, 2003, 2007) are lower resolution and point to high-lake levels between AD 1035 and 1300. Arizona water division
I in northwestern Arizona has reconstructed cool-season precipitation at $\sim$ AD 1190-1210 as a generally wet period (CLIMAS, 2008).

Meko et al. (2007) analyzed tree-ring data for the Colorado River basin and by comparing the results to data for adjacent regions, argued that droughts expanded northward with time during the MWP. Time-transgressive behavior is allowed by our results when compared with Great Basin records, but the data are not sufficiently precise to require time-transgressive behavior.

7.1.1.2. Little Ice Age. The results are consistent with a single episode of river flow and sustained terminal lakes during $\sim \mathrm{AD}$ $1620-1650$ but allow for the possibility of lakes at $\sim$ AD 1460 and $\sim 1530$ as well. Historical records in Europe driven by changes in the North Atlantic Ocean and climate reconstructions for the western US indicate that the LIA was a period of cool temperatures ( $1-2{ }^{\circ} \mathrm{C}$ below historic) and generally enhanced precipitation. Treering analysis of cool-season precipitation in the headwaters of the main rivers of the Mojave Desert by MacDonald (2007) indicates multi-year wet periods at $\sim$ AD $1480, \sim 1540$, and $\sim 1670$. This record is generally consistent with the probable lake timing in the Mojave Desert. A less pronounced wet period at AD 1640 is also present. Because the results represent low-frequency variability better than short wet-year peaks (MacDonald, 2007), it is possible that major floods spaced a few years apart are not well represented. Drought interpretations by Cook and Krusic (2004) show a wet period between AD 1636 and 1661.

Santa Barbara channel SST interpreted from oxygen isotopes in foraminifera (Kennett and Kennett, 2000) provide another proxy for enhanced cool-season precipitation in mountains west of the Mojave Desert. Warm SST, which would enhance southward migration of the Aleutian low, are evident at $\sim$ AD 1400-1450, $\sim 1500, \sim 1560-80$, and $\sim 1680-1720$. A consideration of solar forcing and volcanic eruptions led Mann et al. (2005) to predict pronounced high SST during a period from $\sim$ AD 1650-1680 and at shorter periods during $\mathrm{AD} 1450,1600$, and 1635. Negrini et al. (2006) showed high stands in Tulare Lake during the LIA. Bristlecone pine tree-ring records north of the Mojave Desert have been interpreted as indicating a cool and wet period at $\sim$ AD 1620 (Hughes and Graumlich, 2000; Salzer and Hughes, 2007). The reconstructed record of cool-season precipitation in northwestern Arizona during AD 1608-1617 is one of ten wettest 10-year periods during the past 1000 years (CLIMAS, 2008). Several lakes in basins draining the Sierra Nevada reached high stands at AD 1640-1780 (Stine, 1990; Adams, 2007).

Interpretation of the timing of LIA lakes in the Mojave Desert is not improved by comparison with proxies for climate records at this time, most of which demonstrate a cool period with scattered ages within 50 years or so of the preferred timing for lake high stands. Tree-ring data for the Transverse Ranges (MacDonald, 2007) are consistent with lake interpretations, and allow the possibility of 
any of the intervals noted above as valid lake stands. Other climate reconstructions and lake data are less directly applicable and somewhat inconsistent. However, the preferred timing for Mojave Desert lakes, $\sim$ AD 1650, corresponds with the Maunder Minimum of sunspot activity, which correlates with reduced solar activity.

\subsubsection{Alluvial fans}

The Pleistocene-Holocene transition pulse of alluvial fan aggradation was hypothesized to have been caused by increased erosion as a result of decreased plant cover on hillslopes following the last glacial termination (Bull, 1991). However, the period of climate transition to the modern climate is now known to have lasted from $\sim 15$ to $8 \mathrm{ka}$, and to have a complex structure. At $\sim 8.7 \mathrm{ka}$ widespread warmer and drier conditions of the middle Holocene resulted in widespread xerophytic plant assemblages in the Mojave Desert (Koehler et al., 2005). This middle Holocene period ended at a transition from warm and dry to relatively cooler and wetter at 4.5-3.9 ka (e.g., Anderson and Van Devender, 1991), the start of the late Holocene. These three periods-wet and cool 15-8 ka, dry and warm 8-4 ka, somewhat wet and cool 4-0 ka-have generally been thought to structure geomorphic processes and times of landform development. However, the alluvial fan dates are out of phase with general concepts of these climate periods and transitions among them. This striking mismatch, particularly with climate transitions at $\sim 4 \mathrm{ka}$, if upheld by future studies of alluvial fans, suggests that average temperature and mean annual precipitation are insensitive indicators of geomorphic process drivers for alluvial fan aggradation that is potentially driven by outliers in climatic indicators. It is also notable that alluvial fans were not built during the initial warmer and drier phase after the LGM termination, the Bølling-Alleröd (Fig. 5), but instead several fan dates match the succeeding Younger Dryas and the following one to two thousand years.

The similarities of alluvial fan ages with times of warm SST in Gulf of California (Fig. 6) as revealed by microfauna proxy data is striking (Barron et al., 2005; Barron and Bukry, 2007). Tropical diatoms and silicoflagellates interpreted as indicating warm SST are especially abundant during the Younger Dryas, but persist to $\sim 11 \mathrm{ka}$ and are also present during the Bølling-Alleröd. During much of the early and middle Holocene between $\sim 11$ and $\sim 6.2 \mathrm{ka}$, these tropical phytoplankton are absent from the central Gulf of California, implying cooler SST. Notably, they appear abruptly at $6.2 \mathrm{ka}$, approximately when unit Qya3 fans began aggrading, and are distinctly out of phase with typical timing for the start of the late Holocene cool period.

The concordance of warm Gulf of California SST, which correlates with enhanced North American (Mexican) monsoon activity (Mitchell et al., 2003; Barron et al., 2005) suggests a mechanism for alluvial fan aggradation. More intense and/or more frequent monsoon events may initiate transport of sediment stored on hillslopes resulting in alluvial fan deposition. The mechanism is similar to the tropical cyclone origin for unit Qya4 deposits hypothesized by McDonald et al. (2003) but relies on the spatially smaller monsoons to drive sedimentation in the generally small alluvial fan watersheds of the Mojave Desert. Cyclones driven by tropical Pacific Ocean dynamics as hypothesized by McDonald et al. (2003) to drive fan aggradation may have a larger role during times when Gulf of California SST are reduced, such as the period between 11 and $9 \mathrm{ka}$.

\subsection{Process-response model}

Surface-process records for the Mojave Desert were evaluated in the context of climate conditions, and explained correlations of cool-season Pacific frontal precipitation with lake rises, and warmseason monsoonal precipitation with alluvial fan aggradation. The correlation with storm seasonality suggests a process-response partitioning in the desert landscape.
Understanding of climatic processes in the Mojave Desert advanced considerably in recent years (Merideth, 2000), but key issues regarding atmospheric response times and process transitions remain unresolved. Although the PDO has a high correlation with a variety of climatic-driven responses ranging from production in oceanic fisheries to flood frequency (Mantua et al., 1997; Dettinger et al., 2001), the skill for predicting the summer monsoon properties has remained low even though the monsoon is a dominant feature of precipitation in the southwest U.S. (K. Redmond, oral communication, 1997). Because of a strong relation between the ENSO and winter precipitation, prediction of cool-season climate is more advanced, particularly the prediction of drought occurrence during La Niña conditions. Use of an index, such as the PDO, as the basis for seasonal or annual climate predictions depends on numerous and often tenuous assumptions, including stationarity of atmospheric processes during global warming as well as requiring one index to account for all aspects of climatic variability. The same difficulties occur in increasing proportion when using reconstructed climatic measures that represent average conditions better than extreme events. Extracting seasonality of precipitation and extreme events remains as a daunting task for paleoclimatology.

\subsubsection{Cool-season earth-surface processes}

Although the Mojave Desert generally has $<150 \mathrm{~mm}$ of precipitation annually, evidence for Holocene lake stands in terminal playas of major streams leading from the Transverse Ranges led Enzel et al. (1989) and Enzel and Wells (1997) to investigate climatic and hydrologic conditions that produce ephemeral lakes. They found evidence for five lake stands during the Holocene in Silver Lake, and Drover (1978) found evidence for at least five lake stands in East Cronese Lake. From modeling of precipitation in the Mojave River headwaters of the San Bernardino Mountains, consideration of transmission losses in the river bed, and consideration of evaporation and local basin precipitation inputs, Enzel and Wells (1997) concluded that major cool-season precipitation events $(>100 \mathrm{~mm})$ in the headwaters are necessary to exceed transmission losses in the river bed. Other factors such as evaporation rates and local rainfall on the lake bed are minor. With this conclusion, they examined synoptic climate conditions for flood events in the historical record that created terminal lakes lasting longer than one year. The conditions matching these events included increased winter SST in the Santa Barbara Basin that are associated with weak subtropical highs of the North Pacific and anomalously low pressure along that part of the coast. The low pressure results in a southward shift of the North Pacific low, bringing strong storms into the latitude of the Transverse Ranges. A cut-off low offshore from California may enhance the storms by adding subtropical moisture. These conditions have been correlated with increased floods throughout the southwestern US. (e.g., Ely et al., 1993; Cayan et al., 1999).

Data from East Cronese Lake and Rosamond Lake bolster the regional nature of high stream flow during certain times of the late Holocene. Little Ice Age lakes are now dated by aquatic fauna recovered from lacustrine sediments in these basins and Silver Lake. The age of this fauna suggests that a several-decade-long interval at $\sim$ AD 1650 experienced annual discharge comparable to the historic record floods in several streams issuing from the Transverse Ranges. In addition to the climate patterns suggested by Enzel and Wells (1997) for the LIA, snowpack may have played a role in stream behavior. The LIA was cooler than historic climate and as a result was probably characterized by more snowfall and spring snowmelt runoff in the Transverse Ranges, factors that may have elevated perched aquifers in major streams and reduced transmission losses, enhancing stream flow to terminal lakes (Fig. 7). 


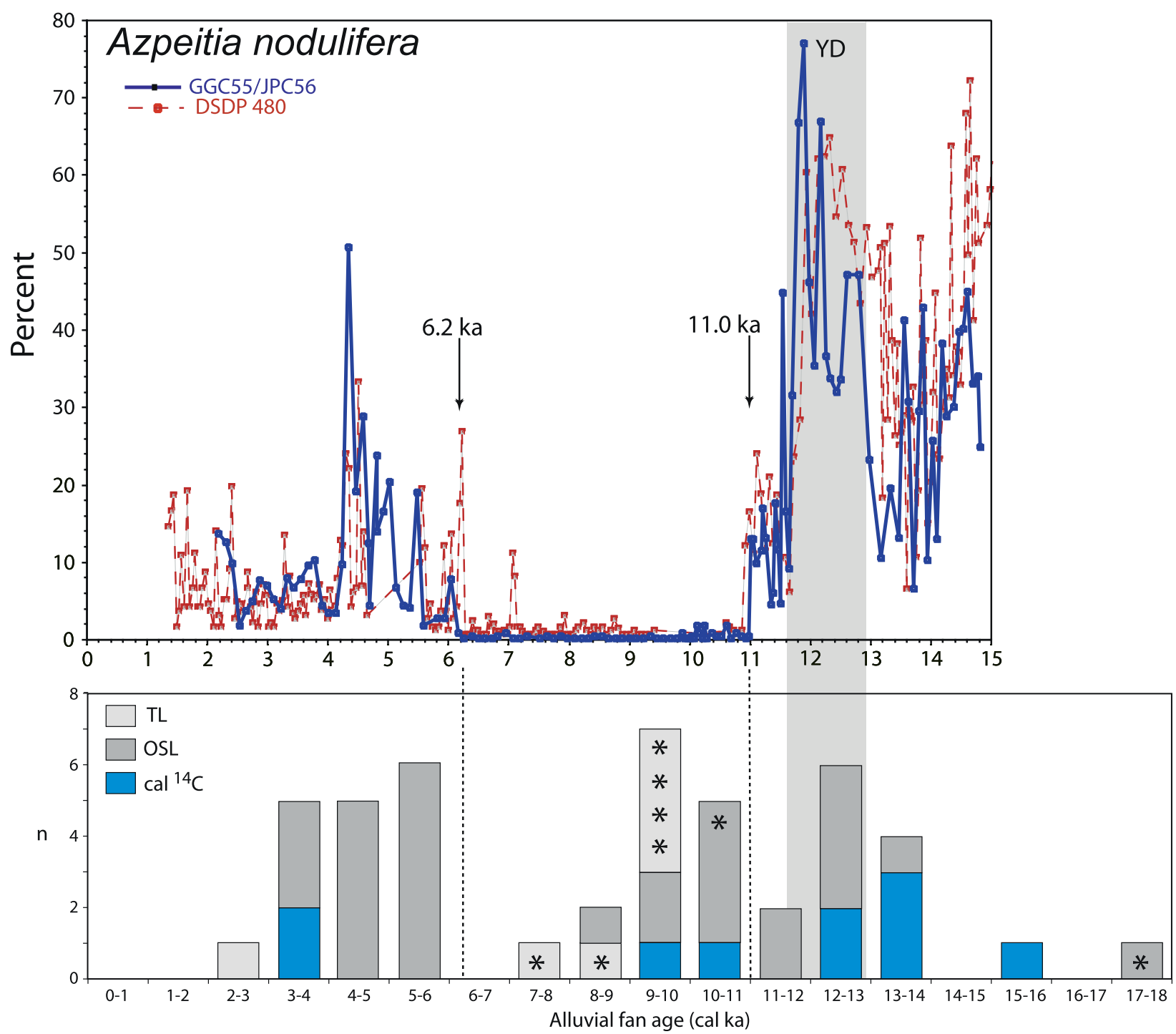

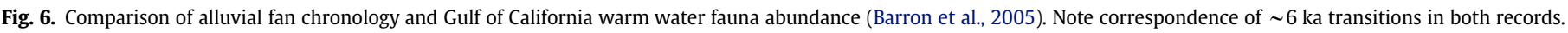
Azpetia nodulifera is a tropical diatom. See Fig. 5 for explanation of histogram. YD, Younger Dryas interval.

The data from Owen et al. (2007) and Mahan et al. (2007a) also support the formation of lake stands at AD 1290 in Cronese Lake, possibly Silver Lake (an undated lacustrine bed between the dated Neoglacial and LIA beds; Enzel and Wells, 1997), and at Silurian Lake. This event is represented not only in drainages headed in the Transverse Ranges, but also in the Salt Creek drainage, which heads in the broad high topography southwest of the Avawatz Mountains (Fig. 1) and drains to Silurian Lake. No historical analogs are available for modeling the precipitation and climatic conditions required to create gravel bars in Silurian Lake, but this event appears to have had more impact in desert drainages than any during the LIA. The East Cronese Lake shorelines, associated with the middens, dated by Owen et al. (2007) at this time interval are $\sim 3 \mathrm{~m}$ higher than LIA shorelines, suggesting that flood frequency or intensity was greater than for LIA. The apparent coincidence of lake stands in the interior desert drainages of Silurian Lake with those of the Mojave River drainage system supports inferences for more and perhaps greater intensity of precipitation events for the $\sim$ AD 1290 lake event than for the LIA.

The AD 1290 lake event occurred during the MWP time of extended average high temperatures (MacDonald et al., 2008). It is broadly similar in timing to lake level rises and expanded river flow in the northern Great Basin (Stine, 1994; Adams, 2003, 2007), and southern San Joaquin Valley (Negrini et al., 2006) from a cool interval within the MWP. The Mono Lake low-stand record as interpreted by Stine (1994), however, is discordant with megadroughts (MacDonald et al., 2008) documented by many workers using dendrochronology methods (e.g., Cook et al., 2004; Mann et al., 2005; Meko et al., 2007; MacDonald, 2007). Compared to the dendrochronology interpretations, the Mojave lakes formed after the two megadroughts. That high-lake levels were sustained in several Mojave Desert drainages during the MWP reinforces the concept that extreme hydrologic events have weak linkages at best to average climatic conditions.

During the MWP and LIA, Santa Barbara basin records indicate general warm SST conditions (Jones and Kennett, 1999), conditions that strongly correlate with enhanced cool-season storm precipitation. Barron et al. (2010), however, suggest that Santa Barbara basin SSTs were cooler between $\sim$ AD 800 and 1350 and generally warmer between $\sim$ AD 1400 and 1800 based on diatom and silicoflagellate assemblages. In contrast, Gulf of California records indicate cool SST and probable weakening of the North American monsoon during the wet interval of the MWP and much of the LIA (Barron and Bukry, 2007). 

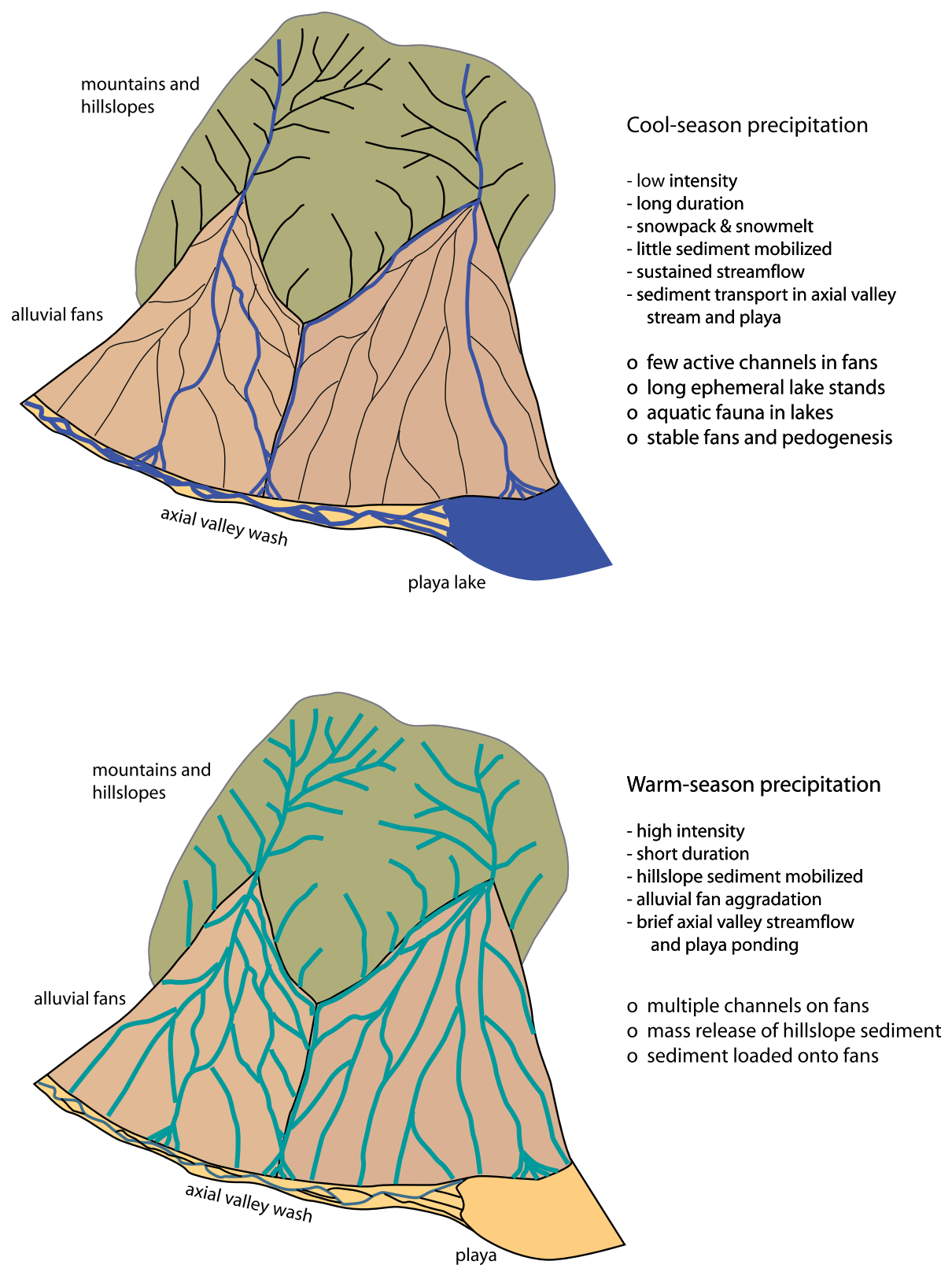

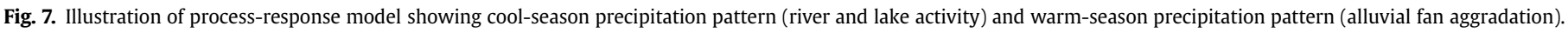

\subsubsection{Warm-season earth-surface processes}

Warm-season storms typically are high-intensity, brief, and spatially restricted cyclonic systems. They historically have affected the eastern Mojave Desert more than the west (Hereford et al., 2006). The high intensity of precipitation in these storms is commonly thought to increase potential for transporting sediment and for exceeding infiltration capacity of typical desert soils. When combined, these processes lead to landscape erosion, local deposition, and sediment transport in channels. Because storms are brief, low-discharge stream flow may lead to sediment deposition only short distances from hillslope erosion sites, leading to alluvial fan aggradation but only very brief playa lake inundations.

Times for Mojave Desert alluvial fan aggradation appear to be out of phase with winter storm activity as recorded by annual precipitation. In general, the middle Holocene has been noted as a period of sustained dry and warm conditions (the altithermal) that ended in various places between $\sim 4.5$ and $3 \mathrm{ka}$. However, alluvial fan aggradation starts at $\sim 6-5 \mathrm{ka}$, seemingly out of phase with the general signal of annual precipitation. Instead, the fan aggradation matches times for increased tropical flora in the Gulf of California, which are interpreted as indicating warmer SST conditions (Barron et al., 2005) and enhanced potential for monsoon storms.

The coincidence of alluvial fan aggradation and warm conditions in the Gulf of California suggests that enhanced summer monsoon activity may drive hillslope erosion and fan aggradation (Fig. 7). Tropical cyclones spawned in the Pacific Ocean also may play a role in alluvial fan aggradation (McDonald et al., 2003) but proxy records for past periods of enhanced cyclone activity are not established and therefore cannot be compared with fan aggradation records. Monsoon activity alone apparently can account for fan aggradation, or the Pacific cyclones contribute as a driver but the record cannot be currently used to evaluate its influence.

\subsubsection{Hillslope processes}

Hillslope processes are modulated by precipitation intensity and duration, plant cover, topography, and soil thickness. High-intensity 
storms cause more sediment erosion and transport, but decreases in plant cover, such as caused by increased temperature and decreased annual precipitation, also can result in accelerated surface erosion and increased landsliding during large-magnitude storms (e.g., Morisawa, 1969; Selby, 1993). On sparsely vegetated piedmonts and desert hillslopes, sediment yields will likely increase in response to increasing frequency and intensity of summer precipitation.

\subsubsection{Connectivity between hillslope, fluvial, and} alluvial fan processes

Times of winter-dominated rainfall and snowfall appear to correlate with enhanced stream flow and ephemeral lakes of longer duration, with relatively little movement of sediment and hillslope erosion in catchments for the streams. In contrast, times inferred to be summer-dominated rainfall appear to correlate with hillslope erosion and transport of sediment short distances onto nearby alluvial fans, causing alluvial fan aggradation but not causing sustained river flow and terminal lake filling. Lower total precipitation, particularly at higher elevations, could reduce groundwater recharge, decreasing base-flow discharge to perennial and larger streams. These conditions would likely diminish regional sedimentation rates in both major rivers and in streams on alluvial fans, where they would reduce avulsions in downstream-branching ephemeral streams. Channels fed by surface-water runoff would be more affected than groundwater-fed channels. If, however, warmer and drier conditions are combined with high-intensity summer monsoons generating infrequent but large-magnitude floods and overland flow, alluvial fans would likely aggrade by delivery of eroded hillslope material as well as from mining of sediment in the upper fan reaches and deposition in the distal fan.

Debris flows, hyperconcentrated flows, and flash floods that provide source material for alluvial fan aggradation occur episodically during intense and prolonged rainfall, and are potentially more pronounced during El Niño climatic conditions. The magnitude and timing, however, of sediment transport and storage in the link between mass wasting processes on hillslopes and alluvial fan aggradation is difficult to constrain (Melton, 1965). Depositional sequences of alluvial fans at an elemental level are a function of the supply and transport of water and sediment. Climatic variability influences weathering and conversion rates of rock to soil (e.g., Heimsath et al., 1997), and hence the availability of sediment as well as the runoff frequency and magnitude directly and indirectly through vegetation response to climate. Given material to transport from steeplands and sufficient water for transport, alluvial fan deposition has been attributed to a wide variety of climatic conditions. From a slope stability perspective, the observation that infrequent, high-intensity storms trigger widespread erosion by overland flow and landsliding is well established in a variety of environments (Katzer et al., 1976; Caine, 1980; Wells and Harvey, 1987; Cannon, 1988; Montgomery et al., 2000). Furthermore, research has demonstrated that sediment aggrades on alluvial fans during extreme events, including hurricanes, under wet and cool climate regimes (Pierce and Scott, 1982; Kochel and Johnson, 1984; Ritter et al., 1995, 2000). In southeastern Arizona, Wohl and Pearthree (1991) documented numerous debris flows occurring during summer monsoonal rains following fire. While Magirl et al. (2007) documented widespread debris flows near Tucson, AZ during a large-magnitude monsoon event, Griffiths et al. (1996, 2004) noted that debris flows in the Grand Canyon resulted from intense convective thunderstorms and were generated by runoff or a "firehose effect" initiation process.

During the relatively wet pluvial intervals of the Pleistocene, bedrock to regolith conversion likely was great, increasing production of hillslope sediment. Deposition of unit Qya4 sediment commenced after the regional pluvial highstand. It has been inferred that during the transition from a wetter to drier climate between the LGM and the beginning of the Holocene, landscapes may have adjusted to changing vegetation, rainfall/runoff patterns, and colluvial cover by eroding hillslopes and aggrading fans (e.g., Bull, 1991). A shift to a drier climate, causing a decrease in the overall canopy cover, can increase both the intensity and amount of precipitation reaching the ground. In addition, decreased root densities arising from a likely shift from trees to shrubs diminishes cohesive reinforcement and relative slope stability. Hence, colluvium that mantled hillslopes during wetter and/or cooler climatic regimes can be transported to fans during the transition to drier and/ or warmer climates. Likewise, Miller et al. (2001) concluded that hillslopes in central Nevada initially responded to drier climates by accelerating hillslope erosion and the concurrent aggradation of tributary and axial-valley system fans.

However, it now appears that the unit Qya4 deposits significantly post-date termination of the LGM and may be associated with a more intense monsoonal climate. Peak Gulf of California SST during the Younger Dryas (Barron et al., 2005) was roughly coincident with one peak of alluvial fan ages in early unit Qya4 time, 14-10 ka. Later unit Qya4 fan ages (10-9 ka) are not synchronous with Gulf of California SST and may show that hillslope response to tropical Pacific Ocean conditions were the result of cyclones (McDonald et al., 2003) or may be a result of plant assemblage changes (Koehler et al., 2005) and increased effective erosion in the absence of rainfall changes. As noted, alluvial fan aggradation has been linked to a spectrum of climatic conditions, with the primary similarity being activity in response to large-magnitude storms. The unit Qya4 alluvial fan aggradation is interpreted as the combination of an extended duration of cool wet conditions accelerating conversion rates of rock to regolith, producing large volumes of stored hillslope sediment, followed (after a lag represented by the Bølling-Alleröd period) by high-intensity storms transporting hillslope sediment to nearby alluvial fans. Although Dorn et al. (1987) concluded from dating of desert varnish that fan aggradation in Death Valley occurred during more humid periods, Wells and McFadden (1987) correctly pointed out that the varnish dates the cessation of fan deposition, not the duration. Nichols et al. (2007) noted that piedmonts composed of grus experience significant time lags between hillslope sediment delivery and deposition down-fan. Rocky fans experience rapid delivery onto the fan and down-fan by energetic debris flows, hyperconcentrated floods, and flash floods, and the lag effect is minimal and within the error of the dating technique.

The widespread unit Qya3 deposits, representing the 6-3 ka time period associated with increased sea-surface temperatures in the Gulf of California, may be driven by the more frequent and more intense warm-season monsoons. This time period corresponds to the highest rates of inferred hillslope erosion in the Kingston Range in the northern Mojave Desert. In a study of a steep, granitic catchment, Schmidt and Menges (2003) calculated volumes of agestratified debris-flow deposits. They noted that although volumes are greatest for Pleistocene deposits, the time-averaged rates of the shorter Holocene epoch exceeded Pleistocene rates by an order of magnitude. These time-averaged rates may be associated with middle Holocene climatic fluctuations modifying tree-line elevations and species compositions, more intense precipitation, and/or fire regime.

\subsubsection{Eolian processes}

Eolian transport is a function of wind speed and duration, sediment size and availability, moisture content, sediment bonding by chemical and/or biologic crusts, and surface roughness, including plant cover (e.g., Lancaster and Tchakerian, 2003). Although wind energy in the Mojave Desert region is typically not a limiting condition, warm daytime temperatures during the 
summer combined with greater atmospheric instability during monsoonal conditions could lead to more thermal convection and stronger winds. A reduction in fine sediment supply from diminished cool-season fluvial transport would tend to lessen sand storms as local sediment sources are depleted. Remobilization of existing eolian deposits or playa fringes, though, can occur by destabilizing disturbances or by altered plant cover in response to decreased soil moisture.

\subsection{Potential effects of global climate change}

Models suggesting warmer winter and summer conditions in the desert and warmer tropical sea-surface conditions have generated concerns that hurricane activity will intensify in the Caribbean Sea and Gulf of Mexico area. Similar results in the Gulf of California might be expected, with a possible consequence of enhanced summer monsoon storm activity in the Mojave Desert. If this landscape-process-response model is correct, climate change may cause more hillslope erosion and alluvial fan aggradation, which could disrupt infrastructure corridors such as aqueducts, pipelines, transmission lines, railroads, and highways; cause sedimentation in diversion channels currently designed to carry sediment-poor water, thereby flooding communities; and cause destructive debris flows that impact mountain communities.

\subsection{Episodic alluvial fan aggradation and soils}

Surface characteristics and soils form discrete mappable entities for alluvial fans of the Mojave Desert area (McFadden et al., 1989; Bull, 1991; Birkeland, 1999). Menges et al. (2001) and Menges and Miller (2007) showed that temporally concurrent aggadation on fans is mappable across wide areas of the desert, suggesting that controls on fan soils and surface characteristics are climatic in origin and driven by coherent regional events. Ambiguity has remained, however, in the question of whether discrete climate events result in unique soil formation or if alluvial fan units are separated by periods of non-deposition, and discrete soils are largely a function of length of time for pedogenesis.

The data suggest that Mojave Desert fans have regionally coherent pulses of aggradation that appear to be separated by periods of non-deposition that probably are represented by dissection and minor stream flow with throughput of sediment to valley bottoms. This result suggests that discrete soils-geomorphic units represent sediment packages that are distinctly different in age and that pedogenic differences are dominated by time differences, rather than climate differences. However, climate differences between pulses of alluvial fan sedimentation should also contribute to the different soils. For instance, differences in precipitation intensity and duration between winter rainfall and summer rainfall should be reflected in depth of soil horizons.

Higher resolution paleoclimate and landscape-process data for the Mojave Desert will test these hypotheses by improving temporal correspondences between geomorphic events and climate conditions. Studies might include developing isotopic proxies for precipitation sources, and then examining paleobotanical and sediment archives for these tracers to establish periods of winter- and summer-dominated precipitation. Another approach is to examine southwest U.S. deserts with historical records for summer dominance of precipitation, evaluating regional differences in landscape responses as a function of climatic conditions.

\section{Conclusions}

The large increase in numeric ages for alluvial fan and lake deposits in the Mojave Desert allows timing of lakes and alluvial fan aggradation events to be evaluated in the context of climatic conditions. The new data strengthen previous models suggesting that enduring lakes in terminal basins are maintained by persistent large-magnitude cool-season storms. Lakes in the Mojave Desert appear to have formed during multi-decade intervals during both the Medieval Warm Period and the Little Ice Age, indicating that the multi-centennial temperature conditions that contrast in these two periods are not significant controls on lake development. Rather, climate variability at the decadal scale is most important for development of persistent lakes. Alluvial fan aggradation, in contrast, responds to different conditions than lake development and records of annual precipitation, and instead closely correlates with increases of Gulf of California SST temperature. This correlation suggests a model of enhanced summer monsoons, which drive hillslope erosion and alluvial fan aggradation. Periods of fan aggradation are 14-9 ka and 6-3 ka. Future climate change may raise tropical SST, increasing monsoon frequency and intensity along with fan aggradation.

\section{Acknowledgements}

We thank several individuals for sharing insights and information on their studies in the Mojave Desert, chief of whom are Scott Anderson, Dave Bedford, Ken Cole, Stephanie Dudash, Nick Lancaster, Rob Negrini, Vicki Pedone, Jeff Pigati, Marith Reheis, Bob Reynolds, John Stock, Steve Wells, and Jim Yount. We also thank Ken Adams, Scott Starratt, and an anonymous reviewer for helpful comments on an earlier version of this paper. Saxon Sharpe and Jim Firby kindly identified Anodonta fossils.

\section{References}

Adamiec, G., Aitken, M.J., 1998. Dose-rate conversion factors: update. Ancient TL 16, 37-49.

Adams, K.D., 2003. Age and paleoclimatic significance of late Holocene lakes in the Carson Sink, NV, USA. Quaternary Research 60, 294-306.

Adams, K.D. 2007. Late Holocene sedimentary environments and lake-level fluctuations at Walker Lake, Nevada, USA. Geological Society of America Bulletin 119, 126-139.

Aitken, M.J., 1985. Thermoluminescence Dating. Academic Press, London, 359 pp.

Aitken, M.J., 1998. An Introduction to Optical Dating. Oxford University Press, Oxford, $267 \mathrm{pp}$.

Amoroso, L., Miller, D.M., 2006. Surficial geologic map and database of the Cuddeback Lake $30^{\prime} \times 60^{\prime}$ quadrangle, San Bernardino and Kern Counties, California. U.S. Geological Survey Open File Report OF 2006-2765, 30 pp., scale 1:100,000.

Anderson, D.E., Wells, S.G., 2003. Late Pleistocene Lake Highstands in Death Valley, California. In: Enzel, Y., Wells, S.G., Lancaster, N. (Eds.), Paleoenvironments and Paleohydrology of the Mojave and Southern Great Basin Deserts. Geological Society of America Special Paper 368, pp. 115-128.

Anderson, K.C., Wells, S.G., 2003. Late Quaternary geology and paleohydrology of Silurian Lake and Salt Spring basin, Silurian Valley, California. In: Enzel, Y., Wells, S.G., Lancaster, N. (Eds.), Paleoenvironments and Paleohydrology of the Mojave and Southern Great Basin Deserts. Geological Society of America Special Paper 368, pp. 129-141.

Anderson, R.S., Van Devender, T.R., 1991. Comparison of pollen and macrofossils in packrat (Neotama) middens: a chronological sequence from the Waterman Mountains of southern Arizona, U.S.A. Review of Palaeobotany and Palynology $68,1-28$.

Banerjee, D., Murray, A.S., Boetter-Jensen, L., Lang, A., 2001. Equivalent dose estimation using a single aliquot of polymineral fine grains. Radiation Measurements 33 (1), 73-94.

Barron, J.A., Bukry, D., 2007. Solar forcing of Gulf of California climate during the past $2000 \mathrm{yr}$ suggested by diatoms and silicoflagellates. Marine Micropaleontology 62, 115-139.

Barron, J.A., Bukry, D., Field, D., 2010. Santa Barbara Basin diatom and silicoflagellate records suggests coincidence of cooler SST with widespread occurrence of drought in the west during the past 2,200 years' for PACLIM Proceedings volume. Quaternary International 215, 34-44.

Barron, J.A., Bukry, D., Dean, W.E., 2005. Paleoceanographic history of the Guaymas Basin, Gulf of California, during the past 15,000 years based on diatoms, silicoflagellates, and biogenic sediments. Marine Micropaleontology 56, 81-102.

Bedford, D.R., 2003. Surficial and bedrock geologic map database of the Kelso 7.5 minute quadrangle, San Bernardino County, California. U.S. Geological Survey Open-File Report OF 2003-501, 34 pp., scale 1:24,000. 
Bedford, D.R., Miller, D.M., Phelps, G., 2006. Preliminary surficial geologic map database of the Amboy $30 \times 60$ minute quadrangle, California. U.S. Geological Survey Open File Report OF 2006-1165, 28 pp., scale 1:100,000.

Bell, J.W., Ramelli, A.R., DePolo, C.M., Maldonado, F., Schmidt, D.L., 1999. Geologic Map of the Corn Creek Springs Quadrangle, Nevada. Nevada Bureau of Mines and Geology Map 121

Berger, R., Meek, N., 1992. Radiocarbon dating of Anodonta in the Mojave River basin. Radiocarbon 34, 578-584.

Birkeland, P.W., 1999. Soils and Geomorphology. Oxford University Press, New York, $430 \mathrm{pp}$.

Blackwelder, E., 1954. Pleistocene lakes and drainages in the Mojave region, southern California. In: Jahns, R.H. (Ed.), The Geology of Southern California. California Division of Mines and Geology Bulletin 170, pp. 35-40.

Budahn, J.R., Wandless, G.A., 2002. Instrumental neutron activation by abbreviated count. In: Taggart Jr., J.E. (Ed.), Analytical Methods for Chemical Analysis of Geologic and Other Materials, U.S. Geological Survey Open-File Report 02-223, 13 pp.

Bull, W.B., 1991. Geomorphic Response to Climatic Change. Oxford University Press, Oxford, $326 \mathrm{pp}$

Bullard, J., Nash, D., North, C., 2007. Drylands - linking landscape processes to sedimentary environments. Geomorphology $85128 \mathrm{pp}$.

Caine, N., 1980. The rainfall intensity-duration control on shallow landslides and debris flows. Geografiska Annaler 62A, 23-27.

Cannon, S.H., 1988. Regional rainfall-threshold conditions for abundant debris-flow activity. In: Ellen, S.D., Wieczorek, G.F. (Eds.), Landslides, Floods, and Marine Effects of the Storm of January 3-5, 1982, in the San Francisco Bay Region, California. U.S. Geological Survey Professional Paper 1434, pp. 35-42.

Carr, W.J., Dickey, D.D., 1980. Geologic map of the Vidal, California, and Pareker SW, California-Arizona quadrangles. U.S. Geological Survey Miscellaneous Investigations Map 1125 scale 1:24,000.

Cayan, D.R., Dettinger, M.D., Diaz, H.F., Graham, N.E., 1998. Decadal variability of precipitation over western North America. Journal of Climate 11, 3148-3166.

Cayan, D.R., Redmond, K.T., Riddle, L.G., 1999. ENSO and hydrologic extremes in the western United States. Journal of Climate 12, 2881-2893.

CLIMAS, 2008. http://www.climas.arizona.edu/research/paleoclimate/background. html (accessed 04.10.08).

Cook, E.R., Krusic, P.J., 2004. North American Summer PDSI Reconstructions: IGBP PAGES/World Data Center for Paleoclimatology Data Contribution Series No. 2004-045. NOAA/NGDC Paleoclimatology Program, Boulder, Colorado, USA, 24 pp.

Cook, E.R., Woodhouse, C.A., Eakin, C.M., Meko, D.M., Stahle, D.W., 2004. Long-term aridity changes in the western United States. Science 306, 1015-1018.

Cooke, R.U., Brunsden, D., Doornkamp, J.C., Jones, D.K.C., 1982. Urban Geomorphology in Drylands. Oxford University Press, Oxford, 324 pp.

Culleton, B.J., 2006. Implications of a freshwater radiocarbon reservoir correction for the timing of late Holocene settlement in Elk Hills, Kern County, California. Journal of Archeological Science 33, 1331-1339.

Dettinger, M.D., Battisti, D.S., Garreaud, R.D., McCabe Jr., G.J., Bitz, C.M., 2001. Interhemispheric effects of interannual and decadal ENSO-like climate variations on the Americas. In: Interhemispheric Climate Linkages. Academic Press, pp. 1-16.

Dorn, R.I., DeNiro, M.J., Ajie, H.O., 1987. Isotopic evidence for climatic influence on alluvial-fan development in Death Valley, California. Geology 15, 108-110.

Drover, C.E., 1978. The Early Prehistoric Ecology of the Northern Mojave Sink, San Bernardino County, California. Unpubl. Ph.D. dissertation. Univ. of California, Riverside, $255 \mathrm{pp}$.

Dudash, S.L., 2006. Preliminary Surficial Geologic Map of a Calico Mountains Piedmont and Part of Coyote Lake, Mojave Desert, San Bernardino County, California. U.S. Geological Survey Open-File Report 06-1090, 48 pp. Pamphlet, scale $1: 24,000$.

Ely, L.L., Enzel, Y., Baker, V.R., Cayan, D.R., 1993. 5000-Year record of extreme paleofloods and associated atmospheric circulation patterns, southwestern United States. Science 262, 410-412.

Enzel, Y., Cayan, R.D., Anderson, R.Y., Wells, S.G., 1989. Atmospheric circulation during Holocene lake stands in the Mojave Desert: evidence of a regional climatic change. Nature 341, 44-48.

Enzel, Y., Wells, S.G., 1997. Extracting Holocene paleohydrology and paleoclimatology information from modern extreme flood events: an example from southern California. Geomorphology 19, 203-226.

Forman, S.L., Pierson, J., 2002. Late Pleistocene luminescence chronology of loess deposition in the Missouri and Mississippi River valleys, United States. Palaeogeography, Palaeoclimatology, Palaeoecology 186 (1 and 2), 25-46.

Graumlich, L., 1993. A 1000-year record of temperature and precipitation in the Sierra Nevada. Quaternary Research 39, 249-255.

Griffiths, P.G., Webb, R.H., Melis, T.S., 1996. Initiation and Frequency of Debris Flows in Grand Canyon, Arizona. U.S. Geological Survey Open-File Report 96-491, 35 pp.

Griffiths, P.G., Webb, R.H., Melis, T.S., 2004. Initiation and frequency of debris flows in Grand Canyon, Arizona. Journal of Geophysical Research, Surface Processes 109, F04002. doi:10.1029/2003JF000077, 14 pp.

Heimsath, A.M., Dietrich, W.E., Nishiizumi, K., Finkel, R.C., 1997. The soil production function and landscape equilibrium. Nature 388, 358-361.

Hereford, R., Webb, R.H., Longpre, C.I., 2006. Precipitation history and ecosystem response to multidecadal precipitation variability in the Mojave Desert region, 1893-2001. Journal of Arid Environments 67, 13-34.
Hughes, M.D., Graumlich, L.J., 2000. Multi-Millennial Nevada Precipitation Reconstruction. International Tree-Ring Data Bank. IGBP PAGES/World Data Centerfor Paleoclimatology Data Contribution Series \#2000-049. NOAA/NGDC Paleoclimatology Program, Boulder CO, USA.

Hunt, C.B., Mabey, D.R., 1966. Stratigraphy and structure, Death Valley, California. In: U.S. Geological Survey Professional Paper 494-A, 162 pp.

Jones, T.L., Kennett, D.J., 1999. Late Holocene sea temperatures along the central California coast. Quaternary Research 51, 74-82.

Katzer, T.L., Glancy, P.A., Harmsen, L., 1976. A Brief Hydrologic Appraisal of the July 3-4, 1975, Flash Flood in Las Vegas Valley, Nevada. U.S. Geological Survey OpenFile Report 76-100, p. 39.

Keefer, W.R., Whitney, J.W., Taylor, E.M., 2004. Quaternary paleoseismology and stratigraphy of the Yucca Mountain area, Nevada. In: U.S. Geological Survey Professional Paper 1689, 212 pp.

Kennett, D.J., Kennett, J.P., 2000. Competitive and cooperative responses to climatic instability in southern California. American Antiquity 65, 379-395.

Kochel, R.C., Johnson, R.A., 1984. Geomorphology and sedimentology of humidtemperate alluvial fans, central Virginia. In: Koster, E., Steel, R. (Eds.), Gravels and Conglomerates, Canadian Society of Petroleum Geologists Memoir, pp. 109-122.

Koehler, P.A., Anderson, R.S., Spaulding, W.G., 2005. Development of vegetation in the central Mojave Desert of California during the late Quaternary. Palaeogeography, Palaeoclimatology, Palaeoecology 215, 297-311.

Lancaster, N., Tchakerian, V.P., 2003. Late Quaternary eolian dynamics, Mojave Desert, California. In: Enzel, Y., Wells, S.G., Lancaster, N. (Eds.), Paleoenvironments and Paleohydrology of the Mojave and Southern Great Basin Deserts. Geological Society of America Special Paper 368, pp. 231-249.

Lang, A., 1994. Infrared stimulated luminescence dating of Holocene reworked silty sediments. Quaternary Science Reviews 13 (5-7), 525-528.

Löhrer, R., 2008. Reliefanalyse an Schwemmfächern und Fußflächen im Südwesten der USA. PhD thesis. RWTH Aachen University, 198 pp.

MacDonald, G.M., 2007. Severe and sustained drought in southern California and the West: Present conditions and insights from the past on causes and impacts. Quaternary International 173-174, 87-100.

MacDonald, G.M., Konstantine, V.K., Hidalgo, H.G., 2008. Southern California and the perfect drought: simultaneous prolonged drought in southern California and the Sacramento and Colorado River systems. Quaternary International 188, 11-23.

Magirl, C.S., Shoemaker, C., Webb, R.H., Schaffner, M., Griffiths, P.G., Pytlak, E., 2007. Debris Flows and Record Floods from Extreme Mesoscale Convective Thun derstorms over the Santa Catalina Mountains, Arizona. U.S. Geological Survey Open-File Report 2007-1108, 1 sheet.

Mahan, S.A. Miller, D.M., Menges, C.M., Yount, J.C., 2007a. Late Quaternary stratigraphy and luminescence geochronology of the northeastern Mojave Desert. Quaternary International 166, 61-78.

Mahan, S.A., Miller, D.M., Menges, C.M., Yount, J.C., 2007b. Late Quaternary stratigraphy and luminescence geochronology of the northeastern Mojave Desert, with emphasis on the Valjean Valley area. In: Miller, D.M., Valin, Z.C. (Eds.), Geomorphology and Tectonics at the Intersection of Silurian and Death Valleys, Southern California, pp. 63-97. U.S. Geological Survey Open-File Report 2007-1424.

Mann, M.E., Cane, M.A., Zebiak, S.E., Clement, A., 2005. Volcanic and solar forcing of the tropical Pacific over the past 1000 years. Journal of Climate 18, 447-456.

Mantua, N.J., Hare, S.R., Zhang, Y., Wallace, J.M., Francis, R.C., 1997. A Pacific interdecadal climate oscillation with impacts on salmon production. Bulletin American Meteorological Society 78, 1069-1079.

McDonald, E.V., McFadden, L.D., 1994. Quaternary stratigraphy of the Providence Mountains piedmont and preliminary age estimates and regional correlations of Quaternary deposits in the eastern Mojave Desert. In: McGill, S.F., Ross, T.M. (Eds.), Geological Investigations of an Active Margin: Geological Society of America Cordilleran Section Meeting Field Trip 8 Guidebook, pp. 205-213.

McDonald, E.V., McFadden, L.D., Wells, S.G., 2003. Regional response of alluvial fans to the Pleistocene-Holocene climatic transition. In: Enzel, Y., Wells, Lancaster, N. (Eds.), Paleoenvironments and Paleohydrology of the Mojave and Southern Great Basin Deserts. Geological Society of America Special Paper 368, pp. 189-205.

McFadden, L.D., Ritter, J.B., Wells, S.G., 1989. Use of multiparameter relative-age methods for age estimation and correlation of alluvial fan surfaces on a desert piedmont Eastern Mojave Desert, California. Quaternary Research 32, 276-290.

McFadden, L.D., Weldon II, R.J., 1987. Rates and process of soil development on Quaternary terraces in Cajon Pass, California. Geological Society of America Bulletin 98, 280-293.

Mejdahl, M., 1979. Thermoluminescence dating: beta dose attenuation in quartz grains. Archaeometry 21, 61-71.

Meko, D.M., Woodhouse, C.A., Baisan, C.H., Knight, T., Lukas, J.L., Hughes, M.K. Salzer, M.W., 2007. Medieval drought in the upper Colorado River basin. Geophysical Research Letters 34, L10705. doi:10.1029/2007GL029988.

Melton, M.A., 1965. The geomorphic and paleoclimatic significance of alluvial deposits in southern Arizona. The Journal of Geology 73 (1), 137.

Menges, C.M., Miller, D.M., 2007. Introduction. In: Miller, D.M., Valin, Z.C. (Eds.) Geomorphology and Tectonics at the Intersection of Silurian and Death Valleys, Southern California, pp. 1-6. U.S. Geological Survey Open-File Report 2007-1424

Menges, C.M. Taylor E.M. Workman, JB Jayko, A.S, 2001. Regional surficialdeposit mapping in the Death Valley area of California and Nevada in support of ground-water modeling. In: Machette, M.N., Johnson, M.L., Slate, J.L. (Eds.) Quaternary and Late Pliocene Geology of the Death Valley Region - Recent Observations on Tectonics, Stratigraphy, and Lake Cycles, Pacific Cell Friends of the Pleistocene Field Trip, February 17-19, 2001, pp. H151-H166. U.S. Geological Survey Open-File Report 01-51. 
Merideth, R., 2000. A Primer on Climatic Variability and Change in the Southwest Udall Center for Studies in Public Policy and the Institute for the Study of Planet Earth, University of Arizona, Tucson, AZ, 29 pp.

Miller, D.M., Amoroso, L., 2006. Preliminary Surficial Geology of the Dove Spring Off-Highway Vehicle Open Area, Mojave Desert, California. U.S. Geological Survey Open-File Report 2006-1265, 22 pp.

Miller, D.M., Bedford, D.R., Hughson, D.L., McDonald, E.V., Robinson, S.E., Schmidt, K.M., 2009. Mapping Mojave Desert ecosystem properties with surficial geology. In: Webb, R.H., Fenstermaker, L.F., Heaton, J.S., Hughson, D.L. McDonald, E.V., Miller, D.M. (Eds.), The Mojave Desert: Ecosystem Processes and Sustainability. University of Nevada Press, pp. 225-251.

Miller, D.M., Menges, C.M., McMackin, M.R., 2007. Geomorphology and tectonics at the intersection of Silurian and Death Valleys, southern California: field trip road log. In: Miller, D.M., Valin, Z.C. (Eds.), Geomorphology and Tectonics at the Intersection of Silurian and Death Valleys, Southern California, pp. 7-49. U.S. Geological Survey Open-File Report 2007-1424.

Miller, J., Germanoski, D., Waltman, K., Tausch, R., Chambers, J., 2001. Influence of late Holocene hillslope processes and landforms on modern channel dynamics in upland watersheds of central Nevada. Geomorphology 38, 373-391.

Mitchell, D.L., Ivanova, D., Rabin, R., Brown, T.J., Redmond, K., 2003. Gulf of California sea surface temperatures and the North American monsoon: mechanistic implications from observations. Journal of Climate 15, 2261-2281.

Montgomery, D.R., Schmidt, K.M., Greenberg, H.M., Dietrich, W.E., 2000. Forest clearing and regional landsliding. Geology 28, 311-314.

Morisawa, M., 1969. Streams: Their Dynamics and Morphology. McGraw-Hill, New York, NY.

Morton, D.M., Campbell, R.H., 1974. Spring mudflows at Wrightwood, Southern California. Quarterly Journal of Engineering Geology and Hydrogeology 7, 377-384

Murray, A.S., Wintle, A.G., 2000. Luminescence dating of quartz using an improved single-aliquot regenerative-dose protocol. Radiation Measurements 32 (1) 57-73.

Murray, A.S., Marten, R., Johnston, A., Martin, P., 1987. Analysis for naturally occurring radionuclides at environmental concentrations by gamma spectrometry. Journal of Radioanalytical and Nuclear Chemistry 115, 263-288.

Negrini, R.M., Wigand, P.E., Draucker, S., Gobalet, K., Gardner, J.K., Sutton, M.Q Yohe II, R.M., 2006. The Rambla highstand shoreline and the Holocene lake-level history of Tulare Lake, California, USA. Quaternary Science Reviews 25, 1599-1618.

Nichols, K.E., Bierman, P.R., Eppes, M.C., Caffee, M., Finkel, R., Larsen, J., 2007. Timing of surficial process changes down a Mojave Desert piedmont. Quaternary Research 68, 151-161.

Ore, H.T., Warren, C.N., 1971. Late Pleistocene-early Holocene geomorphic history of Lake Mojave, California. Geological Society of America Bulletin 82, 2553-2562.

Owen, L.A., Bright, Jordon, Finkel, R.C., Jaiswal, M.K., Kaufman, D.S., Mahan, Shannon, Radtke, Ulrich, Schneider, J.S., Sharp, Warren, Singhvi, A.K. Warren, C.N., 2007. Numerical dating of a late Quaternary spit-shoreline complex at the northern end of Silver Lake playa, Mojave Desert, California: a comparison of the applicability of radiocarbon, luminescence, terrestrial cosmogenic nuclide, electron spin resonance, U-series and amino acid racemization methods. Quaternary International 166, 87-110.

Parry, M.L., Canziani, O.F., Palutikof, J.P., van der Linden, P.J., and Hanson, C.E., Eds., 2008, IPCC, 2007, Climate Change 2007: Impacts, Adaptations and Vulnerability. Contribution of Working Group II to the Fourth Assessment Report of the Intergovernmental Panel on Climate Change. Cambridge University Press, Cambridge, 976 pp.

Pierce, K.L., Scott, W.E., 1982. Pleistocene episodes of alluvial-gravel deposition, southeastern Idaho. In: Fonnischsen, B., Breckenridge, R.M. (Eds.), Cenozoic Geology of Idaho, Idaho Bureau of Mines and Geology, pp. 685-702.

Pigati, J.S., Quade, J., Shanahan, T.M., Haynes, C.V., 2004. Radiocarbon dating of minute gastropods and new constraints on the timing of late Quaternary spring discharge deposits in southern Arizona. Palaeogeography, Palaeoclimatology, Palaeoecology 204, 33-45.

Prescott, J.R., Hutton, J.T., 1988. Cosmic ray and gamma ray dosimetry for TL and ESR. Nuclear Tracks and Radiation Measurements 14, 223-230.

Prescott, J.R., Hutton, J.T., 1994. Cosmic ray contributions to dose rates for luminescence and ESR dating: large depths and long-term time variations. Radiation Measurements 23, 497-500.

Quade, J., Forester, R.M., Whelan, J.F., 2003. Late Quaternary paleohydrologic and paleotemperature change in southern Nevada. In: Enzel, Y., Wells, Lancaster, N. (Eds.), Paleoenvironments and Paleohydrology of the Mojave and Southern Great Basin Deserts. Geological Society of America Special Paper 368, pp. 165-188.

Reheis, M.C., Harden, J.W., McFadden, L.D., Shroba, R.R., 1989. Development rates of late Quaternary soils, Silver Lake playa, California. Soil Science Society of America Journal 53, 1127-1140.
Reheis, M.C., Slate, J.L., Throckmorton, C.K., McGeehin, J.P., Sarna-Wojcicki, A.M., Dengler, L., 1996. Late Quaternary sedimentation on the Leidy Creek fan, Nevada-California: geomorphic responses to climate change. Basin Research 12, 279-299.

Reimer, P.J., Baillie, M.G.L., Bard, E., Bayliss, A., Beck, J.W., Bertrand, C., Blackwell, P.G. Buck, C.E., Burr, G., Cutler, K.B., Damon, P.E., Edwards, R.L., Fairbanks, R.G. Friedrich, M., Guilderson, T.P., Hughen, K.A., Kromer, B., McCormac, F.G., Manning, S., BronkRamsey, C., Reimer, R.W., Remmele, S., Southon, J.R., Stuiver, M., Talamo, S., Taylor, F.W., van der Plicht, J., Weyhenmeyer, C.E., 2004. IntCal04 terrestrial radiocarbon age calibration, 0-26 cal kBP. Radiocarbon 46, 1029-1058.

Richardson, C.A., McDonald, E.V., Busacca, A.J., 1997. Luminescence dating of loess from the northwest United States. Quaternary Science Reviews 16 (3-5), 403-415.

Ritter, J.B., Miller, J.R., Enzel, Y., Wells, S.G., 1995. Reconciling the roles of tectonism and climate in Quaternary alluvial fan evolution. Geology 23, 245-248.

Ritter, J.B., Miller, J.R., Husek-Wulforst, J., 2000. Environmental controls on the evolution of alluvial fans in Buena Vista Valley, North central Nevada, during late Quaternary time. Geomorphology 36, 63-87.

Rockwell, T.K., Lindvall, S., Herzberg, M., Murbach, D., Dawson, T., Berger, G., 2000. Paleoseismology of the Johnson Valley, Kickapoo, and Homestead Valley faults: clustering of earthquakes in the Eastern California shear zone. Bulletin of the Seismological Society of America 90, 1200-1236.

Salzer, M.W., Hughes, M.K., 2007. Bristlecone pine tree rings and volcanic eruptions over the last 5000 yr. Quaternary Research 67, 57-68.

Schmidt, K.M., McMackin, M., 2006. Preliminary Surficial Geologic Map of the Mesquite Lake $30^{\prime} \times 60^{\prime}$ Quadrangle, California and Nevada. U.S. Geological Survey, Open-File Report 2006-1035, Scale 1:100,000, 89 pp.

Schmidt, K.M., Menges, C.M., 2003. Debris-flow deposits and watershed erosion rates near southern Death Valley, CA, United States. In: Rickenmann, D., Chen, C. (Eds.), Debris-flow Hazards Mitigation: Mechanics, Prediction, and Assessment. Millpress, Davos, Switzerland, pp. 219-230.

Selby, M.J., 1993. Hillslope Materials and Processes. Oxford University Press, Oxford UK, $451 \mathrm{pp}$.

Singhvi, A.K., Sharma, Y.P., Agrawal, D.P., 1982. Thermo-luminescence dating of sand dunes in Rajasthan, India. Nature 295 (5847), 313-315.

Snyder, S.L., Duval, J.S., 2003. Design and Construction of a Gamma-ray Spectrometer System for Determining Natural Radioactive Concentrations in Geological Samples at the U.S. Geological Survey in Reston, Virginia. U.S. Geological Survey Open-File Report 03-29 (on-line only). http://pubs.usgs. gov/of/2003/of03-029/.

Sohn, M.F., Mahan, S.A., Knott, J.R., Bowman, D.D., 2007. Luminescence ages for alluvial-fan deposits in Southern Death Valley: implications for climate-driven sedimentation along a tectonically active mountain front. Quaternary International 166, 49-60.

Stine, S., 1990. Late Holocene fluctuations of Mono Lake, eastern California. Palaeogeography, Palaeoclimatology, Palaeoecology 78, 333-381.

Stine, S., 1994. Extreme and persistent drought in California and Patagonia during medieval time. Nature 369, 546-549.

Stock, J.D., Schmidt, K.M., Miller, D.M., 2007. Controls on alluvial fan long-profiles. Geological Society of America Bulletin 120, 619-640,

Stuiver, M., Polach, H.A., 1977. Discussion: reporting of ${ }^{14} \mathrm{C}$ data. Radiocarbon 19 , 355-363.

Stuiver, M., Reimer, P.J., 1993. Extended ${ }^{14} \mathrm{C}$ database and revised CALIB $3.0{ }^{14} \mathrm{C}$ age calibration program. Radiocarbon 35, 215-230.

Thompson, G.D., 1929. The Mohave Desert region, California: a geographic, geologic and hydrologic reconnaissance. In: U.S. Geological Survey Water Supply Paper 578, $572 \mathrm{pp}$

Wells, S.G., McFadden, L.D., 1987. Comment and reply on "Isotopic evidence for climatic influence on alluvial-fan development in Death Valley, California" Geology 15, 1178-1179.

Wells, S.G., Harvey, A.M., 1987. Sedimentologic and geomorphic variations in stormgenerated alluvial fans, Howgill Fells, northwest England. Geological Society of America Bulletin 98, 182-198.

Wells, S.G., Brown, W.J., Enzel, Y., Anderson, R.Y., McFadden, L.D., 2003. Late Quaternary geology and paleohydrology of pluvial Lake Mojave, southern California. In: Enzel, Y., Wells, Lancaster, N. (Eds.), Paleoenvironments and Paleohydrology of the Mojave and Southern Great Basin Deserts. Geological Society of America Special Paper 368, pp. 79-114.

Wohl, E.E., Pearthree, P.P., 1991. Debris flows as geomorphic agents in the Huachuca Mountains of southeastern Arizona. Geomorphology 4, 273-292. 